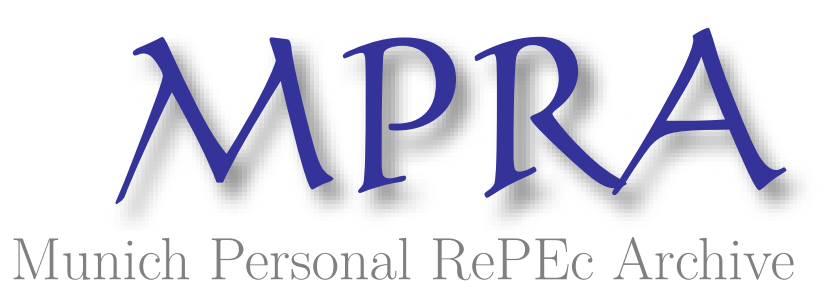

\title{
Macroeconomic Policies and Transmission Dynamics in India
}

Kapur, Muneesh

Reserve Bank of India

21 August 2018

Online at https://mpra.ub.uni-muenchen.de/88566/

MPRA Paper No. 88566, posted 31 Aug 2018 22:36 UTC 


\title{
Macroeconomic Policies and Transmission Dynamics in India
}

\author{
Muneesh Kapur ${ }^{1}$
}

\begin{abstract}
Against the backdrop of the move to an inflation targeting monetary policy framework beginning 2014 with consumer price index (CPI) inflation as the nominal anchor, this paper revisits monetary transmission dynamics. Rather than confining to the typical three equation New Keynesian model, this paper assesses transmission in a broader, disaggregated model incorporating external sector, fiscal policy, banking sector and financial market variables to capture the interactions among key macroeconomic policies and macroeconomic aggregates. The empirical analysis confirms the role of monetary policy in containing demand and inflationary pressures. In view of the ongoing structural reforms, deregulation and opening up of the Indian economy, as well as ongoing initiatives in the monetary policy operating framework to improve the efficacy of monetary transmission, the transmission dynamics can be expected to evolve over time.
\end{abstract}

JEL classification: C30, C53, E31, E32, E43, E52, E58, E63, F31, F32, F41, G12, G21

Keywords: Bank Credit, Bond Yields, Capital Flows, Current Account, Exchange Rate, Fiscal Policy, India, IS curve, Monetary Policy, Monetary Transmission, Phillips Curve, Structural Econometric Model

\section{Introduction}

The Reserve Bank of India transited from the multiple indicator approach towards a flexible inflation targeting (FIT) framework of monetary policy in 2014 (RBI, 2014 and 2015). This arrangement was formalised initially by the monetary policy framework agreement between the Government and the Reserve Bank in February 2015 (Government of India, 2016), and subsequently through amendments to the Reserve Bank of India (RBI) Act in 2016 (RBI, 2016). Consumer price index (CPI) inflation is the nominal anchor under the new framework. The Reserve Bank is mandated with the objective of keeping CPI inflation over the medium-term at 4 per cent, within a band of $+/-2$ per cent, while supporting growth. Prior to this shift in 2014 , the conduct and formulation of monetary policy was anchored on movements in wholesale price index (WPI) inflation. Given the monetary policy focus on WPI inflation in the pre-2014 period, available studies of monetary transmission in India have empirically assessed transmission using WPI inflation (for example, Patra and Kapur, 2012a; Kapur and Behera, 2012).

With the shift towards $\mathrm{CPI}$ inflation based FIT, assessing monetary transmission mechanism in terms of $\mathrm{CPI}$ inflation assumes importance. In a FIT

\footnotetext{
${ }^{1}$ Director, Monetary Policy Department, Reserve Bank of India. The views expressed in the paper are those of the author and not necessarily those of the institution to which he belongs. Inputs and suggestions from Harendra Behera and Joice John and assistance from Sachin Tade are gratefully acknowledged. The usual disclaimer applies.
} 
regime, inflation forecasts take the role of an intermediate target. Accordingly, an understanding of the CPI-based inflation process and its drivers is important for timely and reliable forecasts of inflation. Given the monetary policy transmission lags, the forecasts of inflation and output are, in turn, key inputs to the forward-looking monetary policy. The related aspects such as the size of the exchange rate pass-through, the sacrifice ratio, and the lags with which monetary policy impacts demand and output are also critical. This paper undertakes an assessment of these issues in the context of an estimated New Keynesian macro model of the Indian economy, building upon earlier studies.

While the typical monetary transmission studies in the Indian context have used variants of the compact three-equation New Keynesian model or a vector autoregression (VAR) framework, this paper assesses transmission in a broader modelling framework incorporating external sector (current account balance and capital flows), fiscal policy, banking sector (credit growth and asset quality) and financial market variables (exchange rate and yield on government bonds) to adequately capture the interaction and feedback among the various macroeconomic policies and macroeconomic aggregates. Moreover, the paper assesses inflation dynamics separately for food, fuel and core inflation, and similarly, output dynamics are assessed separately for its major constituents (industry, services and agriculture). Such a richer, disaggregated modelling framework can better capture the interlinkages across sectors and thus provide a fuller assessment of the policy trade-offs.

The paper's empirical analysis confirms the role of monetary policy in containing demand and inflationary pressures. The monetary policy effects on output and inflation are modest, consistent with the existing cross-country and Indian evidence. This suggests that a forward-looking monetary policy can be more effective in achieving its objectives and anchoring inflation expectations at a lower cost vis-a$v i s$ the case of delayed monetary actions - the latter approach might need a stronger monetary policy response especially if inflation expectations get unhinged. A tight monetary policy and low inflation is also found to have a stabilising impact on fiscal dynamics. The model's forecasting performance improves as the forecast horizon increases from the short-term (one quarter ahead) to the medium-term (eight quarters ahead), which is desirable from a policy perspective and also suggests that the interlinkages in the model and its general equilibrium nature add value to the partial analysis inherent in single-equation approaches. A stylised fact of the conduct of monetary policy across major central banks is the inertia in the process of changes in the policy rate ("baby steps" approach). A comparative analysis of monetary policy rules on the appropriate degree of inertia suggests that a less inertial rule has the benefit of minimising deviations of inflation and output from the policy objectives, but such a rule would also require stronger monetary policy responses to any shocks which lead inflation and output to deviate from their policy objectives.

The structure of the paper is as follows. This introductory section is followed by an overview of the transmission channels, with a focus on both cross-country and 
Indian empirical evidence (Section II). The paper's modelling approach, the model structure and data issues are set out in Section III. Empirical results are presented and discussed in Section IV. Model's forecasting performance, properties and simulations are covered and analysed in section $\mathrm{V}$. In view of the regime shift towards a CPI-based framework in 2014, empirical estimates of the monetary policy reaction function based on historical data are challenging and therefore, the model dynamics are also assessed using monetary policy rules from a couple of recent studies. Section VI concludes the paper.

\section{Monetary Transmission: An Overview}

There are four key channels, though not mutually exclusive, of monetary transmission: (a) interest rate channel; (b) quantum channel relating to credit; (c) asset price channel; and (d) exchange rate channel (Boivin, Kiley and Mishkin, 2011; Bernanke and Gertler, 1995). The relative importance of each channel may differ over time and across economies, depending upon factors such as the degree of monetisation of the economy, the extent to which households borrow from the formal financial system, the state of development of financial markets, the instruments available to monetary policy, the fiscal stance and the degree of openness. In the context of very low policy rates in the US during the early 2000 s and in the aftermath of the 2008 financial crisis, a "risk-taking" channel has also been floated, i.e., the interest rate policy and monetary policy stance affects not just the quantity of bank credit, but also its quality (Acharya et al., 2015, Borio and Zhu, 2008; Dell'Ariccia et al., 2016). Too low interest rates for too long in the period prior to the crisis are believed to have helped fuel an asset price boom, spurring financial intermediaries to increase leverage and take on excessive risks. This channel remains pertinent today as interest rates remain lower than the pre-2007 period in major advanced economies (and negative in some cases).

Cross-country empirical evidence, largely based on vector autoregression (VAR) analysis, indicates that: (a) monetary policy impacts growth and inflation with long and variable lags; and, (b) he impact is sensitive to estimation approaches, assumptions and sample periods and may have become less effective since the 1990s (Barakchian and Crowe, 2013; Christiano et al., 1999; Coibion, 2012; Ramey, 2016) (see Annex I for a detailed survey of the findings).

Greater insights into the black box of transmission can be obtained by an analysis of the key pillars of the transmission mechanism, i.e., drivers of inflation, demand/output and monetary policy reaction function. Such an approach is more appropriate, given this paper's objective of understanding transmission dynamics among the various macroeconomic policy instruments and variables. Accordingly, a brief overview of recent literature in this sphere is discussed next ${ }^{2}$.

\footnotetext{
2 This Section partly draws upon the more exhaustive review of the earlier literature in Patra and Kapur (2012a), and Kapur and Behera (2012), and more recent reviews of inflation dynamics in Behera, Wahi and Kapur (2017), and output/demand dynamics in Wahi and Kapur (2018).
} 


\section{Inflation Dynamics}

Analysis of inflation formation and determination in a Phillips curve framework continues to be a key ingredient of understanding monetary transmission. It has attracted more interest since 2008, given the puzzling inflation behaviour (the phenomenon of missing deflation in 2009-10 and missing inflation since 2015) even as there have been sharp and sizable movements in the unemployment rate (large increase during 2009-10 and a sustained decline by 2018 to under 4 per cent, wellbelow its previous estimates of the natural rate). A number of alternative explanations have been offered for this inflation behaviour: stable inflation expectations and a flatter Phillips curve (Blanchard et al., 2015); relatively moderate decline in short-term unemployment rate (as it matters more for inflation than the overall unemployment rate) (Ball and Mazumder, 2015); inflation expectations of households (which are more volatile and elevated) matter and not the relatively stable expectations of financial markets (Coibion and Gorodnichenko, 2015); the Phillips curve might be convex, with the response of inflation to demand conditions being quite muted during recessions vis-à-vis expansions (Gross and Semmler, 2017); and, not only domestic but global factors need to be factored in appropriately (Bobeica and Jarocinski, 2017). Thus, notwithstanding the missing deflation/inflation puzzle, the "US Phillips curve is alive and well (or at least as well as it has been in the past)", but its inability to fully explain inflation dynamics as well as its flattening "raises serious challenges for monetary policy in the future" (Blanchard, 2016; pp. 31 and 34). The flattening of the Phillips curve has important policy implications: "to the extent that the unemployment gap has a smaller effect on inflation, monetary policy rules should put relatively more weight on the unemployment gap relative to inflation. Trying to stabilize inflation may require very large movements in the unemployment gap" (Blanchard et al., 2015).

In the context of a market determined exchange rate and large volatility in capital flows, an assessment of exchange rate pass-through to inflation is critical for inflation management. The magnitude of exchange rate pass-through depends upon a number of factors: monetary policy framework, degree of anchoring of inflation expectations, share of imports in the consumption basket, currency of invoicing and pricing behaviour of firms. Improvements in the credibility of monetary frameworks is believed to have led to declines in pass-through coefficients over the past two decades. Estimates of pass-through coefficients are typically higher in emerging and developing economies compared to advanced economies, inter alia, on account of the less anchored inflation expectations in the former group of countries: the average pass-through coefficient (after 4 quarters) is estimated to be 0.2 for emerging Asian countries, 0.3 for Latin American countries and 0.5 for emerging European countries vis-à-vis 0.1 for advanced economies (IMF, 2016b). BIS (2016) also reports broadly similar pass-through coefficients (around 0.1 for advanced economies and around 0.2 for emerging economies).

The import content of final household consumption expenditure provides one benchmark to assess the pass-through coefficients across countries: a pass-through coefficient above this benchmark can be indicative of second-round effects and a weak 
anchoring of inflation expectations. The import content ratio is estimated to be around 0.25 for the group of advanced economies and slightly below 0.2 for the three emerging groups noted earlier. These import ratios, in conjunction with the estimated pass-through coefficients, indicate the presence of second-round effects in Latin American EMEs and especially in emerging Europe, and, in contrast, well-anchored inflation expectations in advanced economies. Whereas the IMF (2016b) reports evidence of some decline in pass-through coefficients since 2011 attributable, inter alia, to more credible monetary frameworks, BIS (2016) finds some evidence of an uptrend in the pass-through attributable to larger and more persistent exchange rate shocks in the period since 2011-12.

The pass-through is, however, a complex phenomenon and could be reflecting factors other than the imports share. For example, according to Gopinath (2015), international prices, in their currency of invoicing, are not very sensitive to exchange rates at horizons of up to two years. Given the US dollar's domination as invoicing currency in world trade, the US inflation is more insulated from exchange rate shocks, while other countries are highly sensitive to it. Another view articulated by Forbes (2015) posits that the exchange rate's impact on consumer inflation as well as import prices is neither consistent across time, nor related to import intensity of the respective sectors of the economy; what may matter is the nature of the initial exchange rate shock (for example, demand v/s supply shock, or domestic v/s global shock, as is the case with assessment of oil shocks and their impact on the economy). Exchange rate impact can be non-linear: employing big data for euro area, Lewis (2016) estimates that the pass-through of larger exchange rate movements (defined as year-on-year changes of more than 5 per cent) at 0.75 , almost five-times the pass-through coefficient of 0.16 for smaller exchange rate movements. On the other hand, Bergset and Vonen (2016) are not able to find a conclusive evidence in favour of a non-linear pass-through for Norway, although they find some evidence for a larger pass-through for a persistent depreciation vis-à-vis temporary depreciation.

\section{Demand and Output Dynamics}

For a sample of G-7 countries, neither the backward-looking nor the forwardlooking specifications of the pure IS curve yield a negative (and significant) impact of real interest rates on output gap (Goodhart and Hofmann, 2005). This could be due to the simultaneity bias in the estimation (a forward-looking monetary policy might be responding to the expected output gap, which could impart a downward bias to the coefficient on the interest rate in the IS curve) or due to omitted variables (such as long-term interest rates, exchange rate, money supply, asset prices and external demand) that also impact demand. Indeed, in the specifications augmented with property prices (as an indicator of wealth effects), the coefficient on the real interest rate turns out to be negative and significant, solving the IS puzzle: the point estimates suggest that an increase of 100 bps in the real interest rate reduces output by 6-17 bps with a lag of one quarter. The estimates in Rudebusch and Svensson (1999) for the US suggest that a 100 bps increase in the federal funds rate, sustained for 2 years, 
reduces output by 40 bps after 2 years and by 66 bps after 3 years. Hafer and Jones (2008) find a negative and significant coefficient on real interest rate for the G-7 countries only when they augment the IS curve with a monetary aggregate, thereby suggesting that monetary models without money are either premature at best or misguided at worst.

The New Keynesian paradigm takes the expected path of short-term interest rates, with essentially no direct role for long-term interest rates, as the relevant interest rate (Clarida et al., 1999; Woodford, 2003; Kiley, 2014). In contrast, older large-scale macroeconomic models, such as the Federal Reserve's FRB/US model, provide an additional role for long-term interest rates and term/risk premium on demand and output dynamics. For the US, the evidence suggests that the short-term interest rate has a larger influence on economic activity vis-à-vis the long-term rates through its impact on the entire term structure (Kiley, 2014).

Volatile crude oil prices can have a sizable impact on demand, especially for large net oil importers like India, through the discretionary income and terms of trade channels as well as the cost channel (Baumeister and Kilian, 2016). A reduction of 40 per cent in real crude oil prices (with the decline moderating to round 20 per cent five years after the initial shock) could increase global output growth by around one percentage point in the first two years (assuming a full pass-through from the international crude oil prices to domestic prices of petroleum products). Amongst major countries, the peak estimated impact on GDP growth (assuming full pass-through) is around one percentage point in US as well as India, around 40 bps in the euro area and close to 2 percentage points in China (IMF, 2015a).

\section{Monetary Policy Reaction Function}

Cross-country estimates of monetary policy reaction functions - drawing upon Taylor (1993), and its refinements, for example, in Clarida et al. (2000) - indicate a high degree of inertia in the policy rates (coefficient of around 0.85 or more on the lagged interest rate term). This inertia may be due to some omitted variables from the reaction function and which might be quite persistent (Rudebusch, 2006) or may reflect the central bank's desire to smoothen the interest rate changes so as to minimise potential volatility in financial markets from large, abrupt changes (Coibion and Gorodnichenko, 2012). The interest rate smoothing can also be an outcome of a complicated strategic interplay between the central bank and the bond market that arises when the former has some private information about its long-run target for the policy rate and is averse to bond-market volatility (Stein and Sunderam, 2016).

\section{Exchange Rate and External Sector}

In the context of extended period of unconventional monetary policies in the major advanced economies, the impact of exchange rate movements on net exports, and output has attracted renewed interest. Model estimates for the US suggest that a 10 per cent permanent appreciation of the US dollar leads to a reduction of 1-1.5 per cent (after three years) in the US GDP, an improvement of around 1.5 per cent (of 
GDP) in net exports and an increase in core inflation of around 50 bps after 2 quarters (Fischer, 2015). The analysis in IMF (2015b), covering both advanced and emerging market and developing economies, also suggests sizable effects of exchange rate movements on trade volumes: a 10 per cent real effective depreciation is associated with a rise in real net exports of, on average, 1.5 percent of GDP (with substantial cross-country variation of $0.5-3.1$ per cent), and much of the adjustment occurs in the first year. In view of the increased role of global value chains, there has been some weakening of the relationship between exchange rates and trade volumes for some economies and products, but little evidence of a generalised disconnect between exchange rates and external trade as the bulk of global trade still consists of conventional trade. On the other hand, according to Ahmed et al. (2015), participation in global value chains reduces the exchange rate elasticity of manufacturing exports by 22 percent, on average, with greater effect on countries with higher participation in supply chains.

The growth-boosting effect of currency depreciation through the trade channel could, however, get offset, partly or fully, in the presence of sizable foreign currency borrowings; currency depreciations could potentially cripple balance sheets, and curtail activity and overall output. According to BIS (2016), the balance sheet channel of exchange rate dominates the conventional growth-enhancing trade channel in the EMEs in the short-run; in the long-run, however, the net effect of depreciation on growth turns moderately positive, as the conventional trade channel offsets the drag from the risk-taking channel. On the other hand, for advanced economies, currency depreciation is found to boost growth both in the short- and long-run due, as the trade channel's positive effects outweigh the negative effects from the balance sheet channel.

\section{Empirical Evidence: India}

Monetary transmission dynamics for the Indian economy have been studied in a number of studies using alternative approaches and these studies broadly corroborate the cross-country evidence reviewed above ${ }^{3}$. An assessment of monetary transmission in a new Keynesian framework indicates that an increase of 100 bps in the nominal policy rate leads to peak declines of 40 bps (with a lag of 2 quarters) in non-agricultural growth and 25 bps (lag of 5 quarters) in non-food manufactured products WPI inflation; the impact on output and inflation was found to be somewhat lower when real interest rate was used in lieu of nominal interest rate (Kapur and Behera, 2012). Using both firm-level and macroeconomic data, the analysis in RBI (2013) indicates that an increase of 100 bps in real interest rate leads to a reduction of about 50 bps in the investment rate and about 20 bps in GDP growth.

On inflation dynamics, Patra et al. (2014) explore the sources of inflation persistence in India and find (a) supply side shocks in the form of relative price increases, particularly for food, influence aggregate prices lastingly, (b) an increase in

\footnotetext{
${ }^{3} \mathrm{~A}$ brief survey of the findings of the VAR based and other studies on monetary transmission for India is presented in Annex II.
} 
inflation persistence in the post-2008 period, (c) a high degree of interest rate smoothing imparts persistence to the inflation process. According to Sonna et al. (2014), higher real rural wages are the most dominant driver of food inflation. Though statistically significant, the minimum support price (MSP) policy and changing dietary habits in favour of protein items were not as over-bearing as generally perceived. Moreover, the introduction of Mahatma Gandhi National Rural Employment Guarantee Act (MGNREGA) was not found to have caused any significant increase in food inflation as generally perceived. Exchange rate pass-through to inflation is asymmetric (with pass-through from small depreciations being the strongest) and has declined in recent years in an environment of low inflation and declining trade openness (Patra et al., 2018). Behera, Wahi and Kapur (2017) analyse inflation dynamics using subnational data for the new CPI series - the first paper to model the inflation process for the CPI itself (vis-à-vis a few studies, including this paper, focusing on the synthetic $\mathrm{CPI}$ ). Their estimates suggest that, first, the Phillips curve for the CPI inflation is flatter than $\mathrm{CPI}$ for industrial workers (CPI-IW), indicating a higher sacrifice ratio for a given disinflation and, second, a somewhat lower exchange rate pass-through in the case of the CPI inflation vis-à-vis the CPI-IW inflation.

Moving to the IS curve estimates, the output gap has become more persistent (indicative of sluggishness in the adjustment of aggregate demand to tightening structural rigidities and supply bottlenecks) and, the impact of the real policy rate on output has declined (Patra et al. (2017). Salunkhe and Patnaik (2018) focus on the IS curve dynamics for India, and confirm the findings of Patra and Kapur (2012a) on a backward-looking IS model fitting the data better vis-à-vis the hybrid model. Wahi and Kapur (2018) assess the impact of monetary policy and other macroeconomic determinants on economic activity using state-level data. Their integrated empirical framework confirms the role for a countercyclical monetary policy in stabilising economic activity and finds evidence of crowding-in for public investment and crowding-out of other fiscal spending.

Overall, the survey of various studies, both India and cross-country, presented in this section indicates that monetary policy impacts output and inflation with lags, although there is a wide range of estimates on both the lags and the magnitude of the impact. Apart from methodological issues, the differences in findings across studies for a given country could also be on account of structural changes and financial innovations. Such factors can be more important for emerging economies, undergoing a fast pace of structural transformation and continued financial opening (both domestic and global) and deregulation. In India too, the reforms process initiated in the early 1990s and still ongoing can impact transmission impulses over time. Monetary transmission in India also continues to grapple with rigidities emanating, for example, from high SLR, large fiscal deficits, administered interest rates on small savings, and delayed and incomplete pass-through from the central bank's policy signals to commercial bank interest rates (Mohan 2009; RBI, 2014; RBI, 2017; Acharya, 2017). These rigidities have also attracted continuous policy initiatives, aimed specifically at 
improving monetary transmission, which necessitate re-visiting empirics of monetary transmission on a regular basis, as indeed is the objective of this paper.

\section{Modelling Approach, Structure and Data}

\section{Modelling Approach}

The dynamics of an economy can be empirically analysed through three alternative modelling approaches: VAR, DSGE, and structural econometric modelling approaches. Each of these approaches has its strengths and weaknesses. The VAR approach is quite popular for assessing monetary transmission, and its focus on studying dynamics in response to exogenous monetary policy shocks is well-suited to avoid the endogeneity concerns. A severe limitation of this approach, by construction, is that it provides evidence only for the effect of monetary policy shocks, which account for a negligible share of overall interest rate movements, while nothing is learnt about the effect of the more important systematic monetary policy measures (Goodhart and Hofmann, 2005). Indeed, this issue is more relevant now, since true monetary shocks are rare given the more systematic approach to the conduct of monetary policy (Ramey, 2016). Residuals from the VAR regressions used to represent exogenous policy shocks often bear little resemblance to standard interpretations of the historical record of policy actions and the VAR residuals differ across specifications (Walsh, 2010). Apart from this conceptual drawback, the VAR approach has other limitations: atheoretic; restricted ability to handle large variables in the context of short-sample periods; assumption of a backward-looking monetary policy reaction function; and, sensitivity to identifying assumptions.

In contrast to the VAR approach, the DSGE models are rooted in theory and first principles. However, the strong equilibrating assumptions inherent in the DSGE models are debatable and can lead to misleading inferences, as noted by Goodfriend and King (2016) in their review of Riksbank's monetary policy: The models "assumed that the inflation target had such credibility that small changes in current or expected future interest rates would enable the Riksbank to guide inflation back to the target in two years, irrespective of the underlying state of the world economy" (page 91)... "But during the period under review it didn't" (page 84). The existing DSGE models are "seriously flawed" and need to become less insular and less imperialistic (Blanchard, 2018).

An alternative to the DSGE and VAR approaches is the traditional structural econometric model (SEM) approach: structural in the sense of incorporating a good deal of economic theory, and econometric because this is how the equations are typically estimated/parameterised (Wren-Lewis, 2018). The SEM estimation approach has practical advantages over calibrated/DSGE models: better forecasting, being more driven by the historical properties of macroeconomic data; and, easier to use, adapt, and modify, given their reduced-form nature (Gervais and Gosselin, 2014). Therefore, the SEMs can be attractive to the policymakers by giving them confidence 
that the model's predictions are consistent with past evidence vis-à-vis the microfounded DSGE models (Wren-Lewis, 2018) ${ }^{4}$.

Against this backdrop, this paper prefers the SEM approach to assess dynamics among key macroeconomic policies and macroeconomic aggregates. Given the complexity of the economy, no one model or modelling approach can be viewed as ideal in all aspects (Blanchard, 2018); accordingly, the modelling approach used in this paper should be seen as supplementing alternative approaches (calibrated/DSGE models and VAR studies) to draw more robust inferences.

The paper undertakes this endeavour in the New Keynesian framework, augmented with external, financial and fiscal sectors to have a more holistic assessment of the macroeconomic dynamics and interactions. The three-equation core New Keynesian framework models the dynamics of aggregate demand (IS curve, which links demand conditions to interest rate and other factors), aggregate supply (Phillips curve, which links inflationary pressures to cost/demand conditions and other factors), and monetary policy reaction function (Taylor-like rule, which models interest rate responding to deviations of inflation and output from policy targets/objectives) (Clarida, Gali and Gertler, 1998, 1999 and 2000; Gali, 2008; Goodhart and Hoffman, 2005; Taylor, 1993; Paez-Farrell, 2009).

The pure New Keynesian model is fully forward-looking, but is not supported by the observed persistence in the data for a variety of reasons such as habit persistence, liquidity constrained households, and menu costs. Therefore, ad hoc modifications have necessitated hybrid versions of the model, i.e., both forward- and backwardlooking components (Gali and Gertler, 1999; Gali, Gertler, and Lopez-Salido, 2005). Even such hybrid specifications are subject to serious identification and misspecification issues, such as the use of lagged inflation as instruments for expected inflation in the NKPC; in practice, the NKPC is simply a regression of inflation on its lags and the output gap (Rudd and Whelan, 2007; Gordon, 2013). As the exhaustive review by Mavroeidis et al. (2014) notes, seemingly innocuous specification changes lead to big differences in point estimates. For example, adding one lag of inflation to the NKPC tends to reduce the estimated coefficient on expected inflation by about 0.25 , while 4 lags of inflation reduce the coefficient by 0.50 .

Similarly, the available empirical evidence favours backward-looking IS curve. As Fuhrer and Rudebusch (2003) note, the generalized method of moments (GMM) approach to estimating the forward-looking IS curve biases the coefficient on expected output gap towards 0.5 , even though the true coefficient may be below/above 0.5 ;

\footnotetext{
4 "The response of most economists who use microfounded models to the idea that SEMs could be an alternative to DSGE models is normally very simple. SEMs are internally consistent only through luck and good judgement, are therefore subject to the Lucas critique, and therefore cannot produce valid policy conclusions. But the counterargument is straightforward. Microfounded models, because they are unable to match so much of the data (or at least much less than an SEM), are misspecified and therefore cannot produce valid policy conclusions. They are implicitly ignoring real world phenomena that we currently do not fully understand" (Wren-Lewis, 2018, pp.62).
} 
also, the real interest rate has the expected negative and significant effect on output gap only in a backward-looking specification. The panel analysis for 22 OECD countries in Stracca (2010) indicates that the real interest rate turns out to be either insignificant or wrongly signed in forward-looking specifications. Furthermore, the use of backward-looking specifications may be more relevant from policy perspective, since many policymakers appear more comfortable with such a specification (Rudebusch and Svensson, 1999). Backward-looking expectations may be particularly appropriate during the introduction of a new rule for inflation targeting; the assumption of rational expectations may be unrealistic during the transition period, when learning about the new policy rule is taking place. These observations seem all the more relevant in the Indian context in the wake of a regime shift in the conduct of monetary policy with the phased introduction of flexible inflation targeting, beginning early 2014 .

Building upon this stylised empirical evidence on the New Keynesian model, this paper extends the earlier work of Patra and Kapur (2012a) and Kapur and Behera (2012) in a number of directions. First, it takes a disaggregated approach to modelling the output dynamics. Separate equations are estimated for the three major sectors of the economy (viz. agriculture, industry and services output); further detail on the model's structure and equations is presented later in this section. Second, on inflation dynamics, the behaviour of food, fuel and core inflation is also modelled separately, given their different drivers. As noted earlier, the focus is on understanding drivers of $\mathrm{CPI}$ inflation, whereas almost all earlier papers have focussed on determinants of WPI inflation. Third, this paper models exchange rate dynamics for a consistent understanding of the macroeconomic dynamics, while recognising that short-term exchange rate forecasting is beset with many challenges. Fourth, given the high trade and financial integration with the global economy, the behaviour of current account balance and capital flows is also studied. Fifth, drivers of key fiscal indicators (primary fiscal deficit and interest payments) as well as bond yields are explored. Finally, in the context of bank-dominated financial sector, the determinants of bank credit and asset quality are also examined.

A calibrated model of the Indian economy has been recently developed in Benes et al. (2016) and the present paper contributes to further development and refining of such models. Compared to Benes et al. (2016), key additions of this paper are: disaggregated approach to assessing output dynamics; and, incorporation of fiscal, external and financial sector blocks.

\section{Model Structure}

First, following the IS curve framework, demand (output gap, $\tilde{y}$ ) is assumed to depend upon both domestic and external factors [real interest rate gap $(\tilde{r})$, real nonfood bank credit gap $(\widetilde{r n f c})$, monsoon conditions (deviation of actual rainfall from its normal level) $(\widetilde{\text { raln }})$, real effective exchange rate gap $(\widetilde{\text { err }})$, external demand gap $\left(\tilde{y}^{f}\right)$, 
and real domestic mineral oil prices gap $\left.{ }^{5}(\widetilde{\text { mino }} \mathrm{ll})\right]^{6,7}$. Given the potentially different impact of these variables on industrial and services activity, separate equations are estimated for the output dynamics of these two sectors. In contrast, agricultural sector's output dynamics are assumed to be determined only by rainfall dynamics, given the sector's continued, albeit declining, dependence on the monsoon.

$$
\tilde{y}_{t}=\alpha_{1} \tilde{y}_{t-i}+\alpha_{2} \tilde{r}_{t-i}+\alpha_{3} \tilde{y}_{t-i}^{f}+\alpha_{4} \widetilde{r e r}_{t-i}+\alpha_{5} \widetilde{r a l n}_{t-i}+\alpha_{6} \widetilde{r m i n o l l}_{t-i}+\alpha_{7} \widetilde{r n f}_{t-i}+\varepsilon_{t}^{y}
$$

Second, drawing upon the Phillips curve approach, core inflation $\left(\pi^{\text {core }}\right)$ is modelled as a function of domestic demand conditions (overall output gap), inflation expectations, exchange rate movements (Rupees per US dollar) ( $\Delta e$ ), supply shocks [international crude oil prices in US dollar terms $(\Delta o i l)]$. Inflation expectations, in turn, are assumed to have an inertial and adaptive component (proxied by lagged inflation) as well as a forward-looking component (anchored around central bank's inflation target, $\left.\pi^{T}\right)$. Food inflation $\left(\pi^{\text {food }}\right)$ is postulated to depend upon inflation expectations (a weighted average of lagged inflation and the inflation target, as in the case of core inflation), supply shocks [rainfall conditions, inflation in minimum support prices $\left(\pi^{m s p}\right)$, and global food inflation $\left.\left(\pi^{w f o o d}\right)\right]$. Fuel inflation is related to its lag, the central bank's inflation target and international crude oil prices. The inflation terms (lags and expected terms) are constrained to sum to unity for all the inflation equations in consonance with the postulate of no long-run trade-off between growth and inflation (i.e., a vertical long-run Phillips curve is imposed).

$$
\begin{aligned}
& \pi_{t}^{\text {core }}=\beta_{1} \pi_{t-i}^{\text {core }}+\left(1-\beta_{1}\right) \pi_{t}^{T}+\beta_{2} \tilde{y}_{t-i}+\beta_{3} \Delta e_{t-i}+\beta_{4} \Delta o i l_{t-i}+\varepsilon_{t}^{\pi c o r e} \\
& \pi_{t}^{\text {food }}=\beta_{5} \pi_{t-i}^{\text {food }}+\left(1-\beta_{5}\right) \pi_{t}^{T}+\beta_{6} \widetilde{r a l n}_{t-i}+\beta_{7} \pi_{t-i}^{\text {wfood }}+\beta_{8} \pi_{t-i}^{\text {msp }}+\varepsilon_{t}^{\pi f o o d} \\
& \pi_{t}^{\text {fuel }}=\beta_{9} \pi_{t-i}^{\text {fuel }}+\left(1-\beta_{9}\right) \pi_{t}^{T}+\beta_{10} \Delta o i l_{t-i}+\varepsilon_{t}^{\pi f u e l}
\end{aligned}
$$

\footnotetext{
${ }^{5}$ As most of the sample period was marked by delayed and incomplete pass-through from international crude oil prices to domestic product prices and also due to occasional changes in the tax rates on the domestic product prices, the correlation between domestic product prices and international crude oil prices is weak. In order to better capture the impact of oil shocks on domestic demand and economic activity, movements in the WPI mineral oils index, rather than global crude oil prices, are taken as the explanatory variable in the IS curve regressions.

${ }^{6}$ Variables with tilde $(\sim)$ on top are in gap form, calculated as deviation of actual from longterm trend.

${ }^{7}$ Real variables have been obtained by deflating the relevant nominal variables with consumer price index (or consumer price inflation in the case of interest rates). The real effective exchange rate is taken from OECD database.
} 
Third, for the monetary policy reaction function and the final equation of the core New Keynesian model, the nominal policy interest rate $(I)$ is postulated to be driven by deviations of expected inflation and expected output from their respective targets/objectives and foreign policy interest rate $\left(i^{i}\right)$. As elaborated later, an empirical assessment of this rule in terms of $\mathrm{CPI}$ inflation raises issues, since the monetary policy stance over most of the sample period was largely conditioned by movements in WPI inflation, although CPI inflation was monitored as a part of the multiple indicators approach.

$i_{t}=\gamma_{0}+\gamma_{1} i_{t-1}+\gamma_{2} E_{t} \tilde{y}_{t+1}+\gamma_{3} E_{t}\left(\pi_{t+i}-\pi_{t}^{T}\right)+\gamma_{4} i_{t-1}^{f}+\varepsilon_{t}^{p o l}$

Fourth, exchange rate movements $(\Delta e)$ are postulated to be driven by relative inflation rates (Indian CPI inflation relative to the US inflation, $\Delta r p$ ). The purchasing power parity (PPP) principle is assumed to hold in the long-run - the coefficients on the exchange rate and the relative inflation terms are, thus, restricted to sum to unity. In the short-run, given India's increased external openness, deviations from the PPP can be sizable and persistent under the impact of volatile capital flows $(k f)$ and volatility in global financial markets (vix) and therefore, these variables are also included amongst the explanatory variables.

$\Delta e_{t}=\omega_{0}+\omega_{1} \Delta e_{t-i}+\left(1-\omega_{1}\right) \Delta r p_{t-i}+\omega_{2} k f_{t-i}+\omega_{3} c a b_{t-i}+\omega_{4} \Delta v i x_{t-i}+\varepsilon_{t}^{e}$

Fifth, current account balance (as per cent to GDP) (cab) is modelled as driven by both domestic and global factors, while also taking into account India's large dependence upon oil imports for its domestic needs [domestic growth $(\Delta y)$, real effective exchange rate $(\Delta r e r)$, global demand $\left(y^{\prime}\right)$, and global crude oil prices $\left.(\Delta o i)\right]$. Sixth, for net capital flows (as per cent to GDP) $(k f)$, both push and pull factors domestic growth $\left(\Delta y_{t}\right)$, interest rate differentials $\left(i-i^{*}\right)$ and movements in the nominal exchange rate - are included as potential explanatory variables.

$$
\begin{aligned}
& c a b_{t}=\varphi_{0}+\varphi_{1} c a b_{t-i}+\varphi_{2} \Delta y_{t-i}+\varphi_{3} \Delta y_{t-i}^{f}+\varphi_{4} \Delta r e r_{t-i}+\varphi_{5} \Delta o i l_{t-i}+\varepsilon_{t}^{c a b} \\
& k f_{t}=\vartheta_{0}+\vartheta_{1} k f_{t-i}+\vartheta_{2}\left(i-i^{*}\right)_{t-i}+\vartheta_{3} \Delta e_{t}+\vartheta_{4} \Delta y_{t}+\varepsilon_{t}^{k f}
\end{aligned}
$$

Seventh, real non-food bank credit $(\Delta r n f c)$, and banks' non-performing assets (npa) are modelled as a function of economic activity, and real interest rate $(r)$. Real oil prices $(\Delta r o i)$ are included to capture the impact of fluctuations in global crude prices on demand for bank credit from the domestic banking system.

$$
\begin{aligned}
\Delta r n f c_{t} & =c_{1}+\delta_{1} \Delta r n f c_{t-1}+\delta_{2} \Delta n p a_{t-i}+\delta_{3} \Delta y_{t-i}+\delta_{4} \Delta r_{t-i}+\delta_{5} \Delta r o i l_{t-i}+\varepsilon_{t}^{n f c} \\
\Delta n p a_{t} & =c_{2}+\delta_{6} \widetilde{r n f} c_{t-1}+\delta_{7} \Delta n p a_{t-i}+\delta_{8} \Delta y_{t-i}+\delta_{9} \Delta r_{t-i}+\varepsilon_{t}^{n f c}
\end{aligned}
$$


Eighth, the central government's primary revenue deficit ( $p r d)$ is assumed to be influenced by real economic activity (through its impact on government revenues) and inflation (through its impact on government expenditures). Given the administered nature of prices of domestic petroleum products over most of the sample period, there was incomplete pass-through from global crude oil prices to domestic prices, with implications for government's deficit. Therefore, crude oil prices are also included as an explanatory variable. As excess/scanty rainfall impacts the agricultural and the rural sector and in turn potentially impacts government expenditures, rainfall is also included in the equation. Ninth, government's interest payments (ip) are modelled as a function of the outstanding debt stock (liab) and movements in government bond yields $(g s)$.

$\operatorname{prd}_{t}=\xi_{0}+\xi_{1} p r d_{t-i}+\xi_{2} \Delta y_{t-i}+\xi_{3} \Delta o i l_{t-i}+\xi_{4} \pi_{t}+\xi_{5} \widetilde{r a l n}_{t-i}+\varepsilon_{t}^{p r d}$

$i p_{t}=\lambda_{0}+\lambda_{1} l i a b_{t-i}+\lambda_{2} g s_{t-i}+\varepsilon_{t}^{i p}$

Finally, government bond yields are expected to be driven by monetary and liquidity measures [policy repo rate, cash reserve ratio (crr), statutory liquidity ratio $(s / r)]$, government's financing needs (gross market borrowings, gmb), investments by non-residents in government bonds (fiidebt), foreign bond yields $\left(i^{*}\right)$, and crude oil prices. Crude oil prices are included to account for their possible impact on government's deficit and borrowings in view of the earlier noted phenomenon of incomplete pass-through over the sample period.

$$
\begin{aligned}
& \Delta g s_{t}=\mu_{0}+\mu_{1} \Delta g s_{t}+\mu_{2} \Delta i_{t-i}+\mu_{3} \Delta c r r_{t-i}+\mu_{4} \Delta s l r_{t-i}+\mu_{5} g m b_{t-i}+\mu_{6} \text { fiidebt }_{t-i}+ \\
& \mu_{7} \Delta o i l+\mu_{8} \Delta i^{*}+\varepsilon_{t}^{g s}
\end{aligned}
$$

Data

All-India CPI inflation data are available from 2010 onwards only; following Benes et al. (2016), this series has been backcasted to 2001 by combining weights from all-India CPI with inflation rates from for CPI (industrial workers) for the period prior to 2010. The sample period for estimation in this paper therefore starts from the quarter April-June 2001 (or later in some cases) and ends in the quarter ended March 2016. All the data used in the paper are available in public domain, and have been accessed from a variety of sources. Data on domestic variables are from Reserve Bank of India's database/publications, and Central Statistics Office. Data on international variables have been taken from International Monetary Fund (global exports, international crude oil prices, and commodity prices) and Federal Reserve Bank of St. Louis (VIX, US federal funds rates, US yields and US consumer prices). Data on real effective exchange rate (CPI-based) for India are from Organisation for Economic Cooperation and Development.

Data series have been de-seasonalised using X12-ARIMA procedure, except for financial market and a few other variables (interest rates, nominal exchange rate, crude oil prices and minimum support prices) which have been used without 
adjustment. Various gap terms (for example, output gap, real interest rate gap, real exchange rate gap, credit gap) have been computed as the log-difference (and multiplied by 100 to make them in percentage terms) of the (seasonally adjusted) actual series and its Hodrick-Prescott (HP) filtered series. Inflation rates and growth rates are computed as quarter-over-quarter (log) changes (and multiplied by 100 for percentage terms) and annualised, unless specified otherwise.

Nominal policy interest rate is captured by the effective policy rate, following Patra and Kapur (2012a), in view of the operating rate shifting between repo rate and reverse repo rate for the earlier part of the sample period. Real interest rate is computed as the effective policy rate less the 4-quarter average of year-on-year CPI inflation, with the latter term being a proxy for expected inflation. The variable names and their description are provided in Table 1. The unit root tests (Augmented DickeyFuller and Phillips-Perron tests) indicate that the null of unit root (non-stationarity) can be rejected for all variables except two at 10 per cent levels based on either of the two tests (Table 2). Equations with contemporaneous endogenous variables or with forward-looking variables as explanatory variables have been estimated through generalised method of moments (GMM) approach; in other cases, ordinary least squares (OLS) approach has been used ${ }^{8}$.

\section{Empirical Results}

Starting with the IS curve, all the explanatory variables have the expected signs and satisfy the regression diagnostics: higher real interest rates, lower volume of bank credit, lower global demand, real exchange rate appreciation, higher oil prices and weak monsoon depress demand in both the industrial and the services sectors. As expected, estimates indicate relatively stronger impact of these variables on industrial activity vis-à-vis services activity. An increase of 100 bps in the real policy rate, ceteris paribus, can reduce domestic demand by 20-50 bps in the non-agricultural sector, while one percent appreciation of the real effective exchange rate can reduce domestic demand by 7-15 bps. On the other hand, one per cent higher global exports can boost domestic demand by 25-35 bps. Rainfall activity is found to affect not only agricultural activity but also demand in the non-agricultural sector, given the still substantial share of agricultural sector in overall GDP and an even more substantial share of workforce dependent upon the farm sector. Fiscal variables (such as revenue deficit or gross fiscal deficit, headline or cyclically adjusted) were also tried in the industry and services equations to capture the impact of government spending on activity; however, these did not turn out to be statistically significant. It is interesting to note that in the statelevel panel analysis in Wahi and Kapur (2018), higher capital outlays by the state governments boost output with a lag; in contrast, higher deficits were found to crowd out economic activity.

\footnotetext{
${ }^{8}$ All data transformations, estimations and simulations have been undertaken in the software WinRATS (version 9.2). Model dynamics in response to various shocks have been estimated using IRIS and MATLAB.
} 


$$
\begin{aligned}
& \text { YINDGAP }_{\mathrm{t}}=-0.01 \mathrm{YINDGAP}_{\mathrm{t}-1}-0.52 \mathrm{EFF}_{-} \mathrm{RGAP}_{\mathrm{t}-4}+0.36 \mathrm{WEXPGAP}_{\mathrm{t}}-0.15 \text { REERGAP }_{\mathrm{t}-1} \\
& +0.05 \text { RAIN }_{\mathrm{t}-3}-0.20 \text { RMINOILGAP }_{\mathrm{t}-1}+0.25 \text { RNFCGAP }_{\mathrm{t}-2} \\
& \text { (2.1) }
\end{aligned}
$$

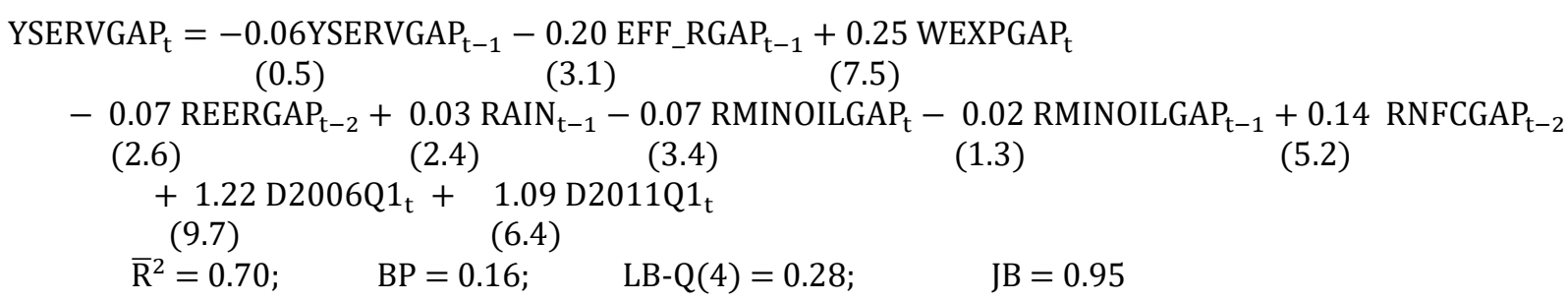

$$
\begin{aligned}
& \text { YAGRIGAP }_{\mathrm{t}}=0.53 \text { YAGRIGAP }_{\mathrm{t}-1}+0.05 \text { RAIN }_{\mathrm{t}}+0.23 \text { RAIN }_{\mathrm{t}-1}+4.16 \text { D2007Q4 }_{\mathrm{t}}-2.37 \text { D2008Q1 }_{\mathrm{t}} \\
& \text { (7.2) } \\
& \text { (2.9) } \\
& \text { (6.4) } \\
& \text { (20.3) }
\end{aligned}
$$

All variable names, as noted earlier, are in Table 1. In all the regression results, figures in parenthesis are t-statistics based on heteroscedasticity and autocorrelation consistent (HAC)-corrected standard errors. The diagnostic tests reported - LB-Q, JB, and BP - are significance level ( $p$-value) of Box-Pierce-Ljung $Q$-statistic for the null of no residual autocorrelation up to 4 lags, of Jarque-Bera test for the null of normality of residuals, and Breusch-Pagan (BP) test for the null of no heteroscedasticity of residuals, respectively.

Turning to the inflation process, results confirm the role of persistence, excess demand conditions, exchange rate movements and oil prices in pushing core inflation. According to estimated coefficients, an output gap of one per cent (i.e., actual output exceeds potential output by one per cent) and a depreciation of 10 per cent of the domestic currency could increase core inflation by around 60 bps and 40 bps, respectively. An increase of 10 per cent in international crude oil prices increases core inflation by around $30 \mathrm{bps}^{10}$. Sharp variations in core inflation were observed in quarters 2004:Q3, 2005:Q1, 2009:Q3, and 2010:Q1 on account of the upward adjustment in house rent allowances for government employees, and these are captured through appropriate dummies.

\footnotetext{
${ }^{9}$ The $p$-value of the White test for the null of non-heteroscedasticity of residuals is 0.20 .

${ }^{10}$ In view of the earlier noted wedge between domestic product prices and international crude oil prices due to delayed/incomplete pass-through over most of the sample period as also due to taxation changes, the estimates of the coefficients on global oil prices appear to be biased downwards. Drawing upon the estimates in Behera, Wahi and Kapur (2017), the equation is estimated by imposing the restriction that the sum of the oil coefficients is 0.03 . In case of the food inflation equation, the coefficient is restricted to 0.02 .
} 


$$
\begin{aligned}
& \text { D4LCPIEXFF } F_{t}=0.62 \text { D4LCPIEXFF4Q } Q_{t-1}+0.38 \text { INFCPI }_{-} T_{t}+0.61 \text { GDPRGAP }_{t-1}+0.04 \text { D4LEXCH }_{t-1} \\
& \text { (6.4) (4.0) (4.2) (3.1) } \\
& +0.015 \text { D4LOIL }_{t-1}+0.015 \text { D4LOIL }_{t-4}+2.86 \text { D2004Q3 }_{t}+4.96 \mathrm{D}^{2005 Q 1} 1_{t} \\
& \text { (6.2) (5.9) (9.4) (17.3) } \\
& +9.04 D 2009 Q 3_{t}+7.86 D 2010 Q 1_{t}+9.33 D 2011 Q 1_{t}-7.07 D 2012 Q 1_{t} \\
& \overline{\mathrm{R}}^{2}=0.77 ; \quad B P=0.54 ; \quad L B-Q(4)=0.58 ; \quad J B=0.43
\end{aligned}
$$

Moving to food inflation dynamics, higher minimum support prices and higher global food and oil prices impart upward pressure on domestic food inflation. Exchange rate movements also impact food inflation through their impact on the domestic currency prices of global food and oil prices (which enter the equation in rupee terms). Above normal rainfall has a soothing impact on food inflation, although the variable is not significant. As expected, food inflation is somewhat less persistent than core inflation in view of it being subject to recurrent supply shocks. In case of fuel group inflation, global crude oil prices (in rupee terms) are found to have a lagged impact $^{11}$.

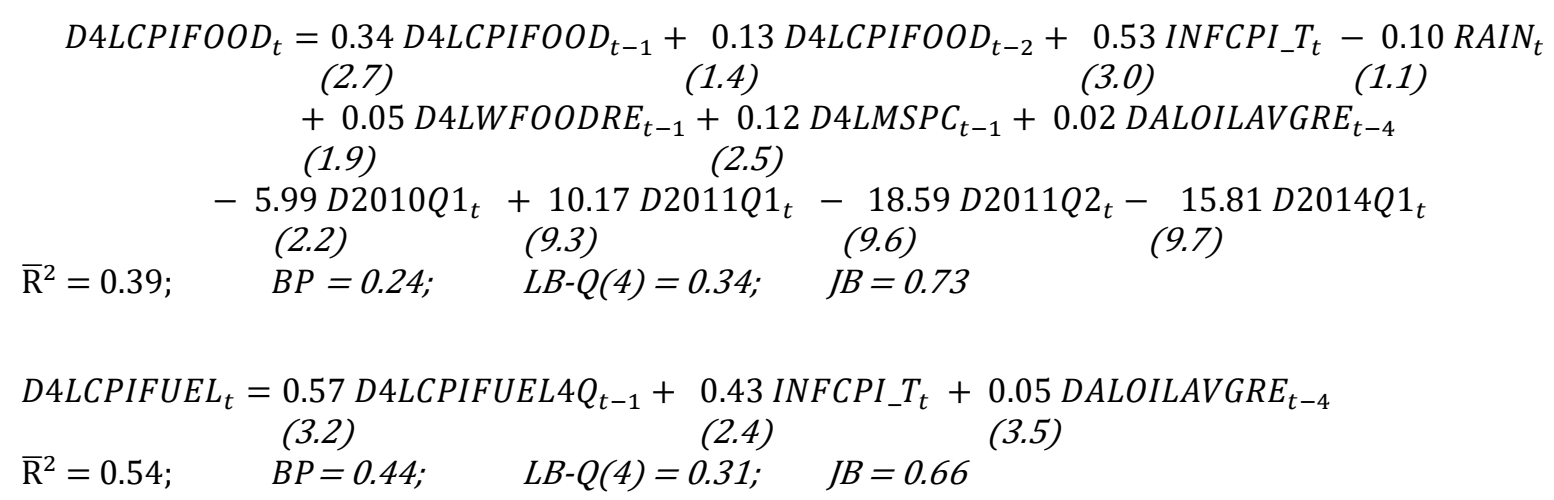

An accurate empirical assessment of the monetary policy reaction function in terms of CPI inflation, as noted earlier, is hindered by the fact that the conduct and formulation of monetary policy over most of the sample period was largely conditioned by movements in WPI inflation. The Taylor-like rule using WPI inflation has the correct signs and also satisfies the Taylor-principle of long-run coefficient on the inflation gap being above unity ${ }^{12}$. In view of these empirical issues, the central bank's reaction to the CPI inflation is assumed to be the same as was the case with the WPI inflation and therefore the coefficients from the WPI-based reaction function are used. This

\footnotetext{
${ }^{11}$ The sample period for the fuel inflation equation is 2011-2016.

12 The equation is estimated by GMM approach, with 2 lags of the following variables as instruments: EFF, GDPRGAP, WEXPRGAP, DALCPIIWGAP, DALWPIGAP, DALWNFUEL, DALOIL, D4LEXCH, DALNFC, and FEDTARGET. The foreign exchange market pressure in the aftermath of the taper tantrum led to a large, temporary increase in the marginal standing facility rate (and hence the effective policy rate) in July 2013 and this was rolled back in a phased manner in September-October 2013. This impact is captured through a dummy for 2013:Q3.
} 
approach is admittedly naïve, and as a robustness test, the model dynamics are also assessed in response to alternative reaction functions later on in this section.

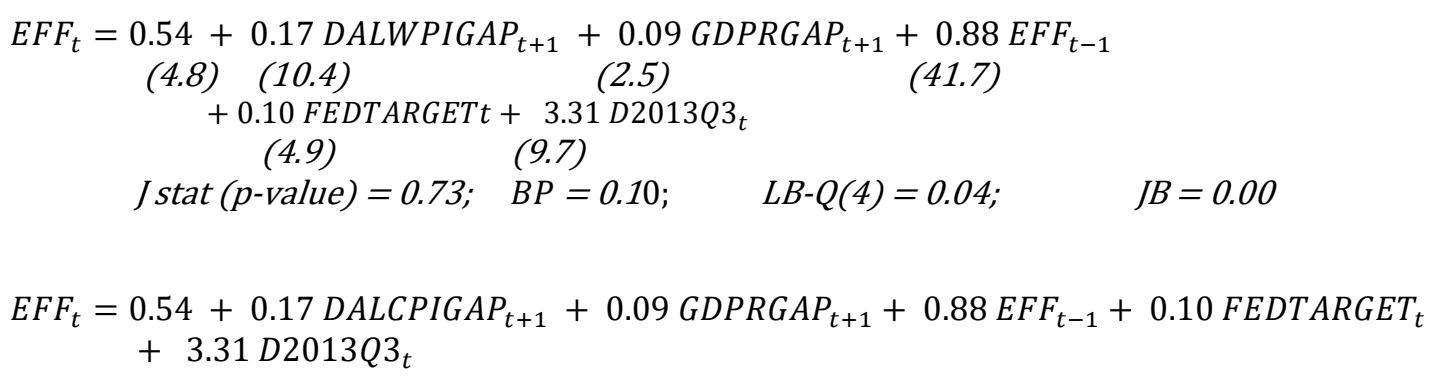

On exchange rate dynamics, regression estimates indicate that higher relative domestic inflation as also higher global financial market volatility (captured by VIX) put depreciation pressure on the domestic currency, while higher capital flows impart an appreciation pressure, consistent with conventional wisdom ${ }^{13}$.

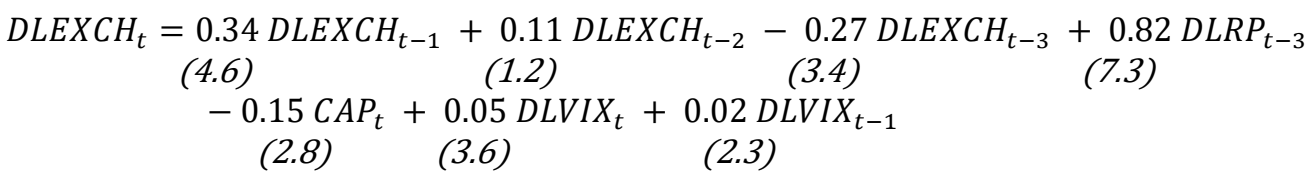

Moving to the external sector block, the current account balance $(C A B)$ shows a deterioration on the back of higher domestic industrial activity, real appreciation and higher global crude oil prices; on the other hand, higher global demand leads to an improvement in the $\mathrm{CAB}^{15}$. Estimates indicate that one percentage point higher global growth, ceteris paribus, improves the CAB (i.e., increases the surplus or reduces the deficit) by around 0.2 per cent of GDP over the long-run, while a similar order of increase in domestic industrial activity reduces $C A B$ (i.e., widens the deficit) by around 0.3 per cent of GDP.

$$
\begin{aligned}
& C A B_{t}=0.09+0.89 \text { CAB }_{t-1}-0.03 \text { D4LYIND }_{t-3}+0.02 \text { D4LWEXPR }_{t-3} \\
& \text { (0.4) (14.0) (2.2) (2.1) } \\
& \text { - } 0.05 \text { DALREER }_{t-5}-0.01 \text { D4LOILRE }_{t-1}-4.87 \text { D2004Q3 }_{t}+2.76 \text { D2013Q3 }_{t} \\
& \text { (2.0) (3.5) (14.3) (7.2) } \\
& \bar{R}^{2}=0.75 ; \quad B P=0.75 ; \quad L B-Q(4)=0.22 ; \quad J B=0.96
\end{aligned}
$$

Net capital flows are found to respond to both push and pull factors on the expected lines. Higher domestic growth, and higher domestic interest rates are associated with higher capital flows, while domestic currency depreciation reduces

\footnotetext{
${ }^{13}$ The equation is estimated using the GMM approach, with 2 lags of DLRP, REERGAP, CAB, CAP, DLOILAVG, DLVIX and 4 lags of DLEXCH as instruments:

${ }^{14}$ The $p$-value of the White test for the null of non-heteroscedasticity of residuals is 0.20 .

${ }^{15}$ Restrictions on gold imports were imposed in the third quarter of 2013 to manage the foreign exchange market volatility after the taper episode, leading to a sharp reduction in the current account deficit and a dummy is accordingly included.
} 
capital flows ${ }^{16}$. Point estimates suggest that the impact effect of one percentage point higher domestic growth or higher domestic interest rate each is an increase of capital flows of around 0.3-0.4 per cent of GDP.

$$
\begin{gathered}
\text { CAP }_{t}=-1.33+0.29 \mathrm{CAP}_{t-1}+0.43 \mathrm{INTDIF}_{t}-0.07 \mathrm{DHLEXCH}_{t} \\
(3.0)(4.6) \quad(4.7) \quad(7.0) \\
+0.29 D A L G D P R_{t}+5.24 D 2004 Q 4_{t}+6.83 D 2007 Q 3_{t} \\
(4.3) \quad(2.8) \quad(4.2) \\
\text { Jstat }(p-\text { value })=0.94 ; \quad B P=0.38 ; \quad L B-Q(4)=0.69 ; \quad J B=0.60
\end{gathered}
$$

Moving to the fiscal block, higher domestic non-agricultural activity is found to reduce primary revenue deficit, while higher domestic inflation, higher crude oil prices and rainfall deficiency widen the deficit ${ }^{17}$. According to point estimates, lower inflation might be more conducive for fiscal consolidation than higher growth: the deficit widening associated with one percentage point higher inflation ( 0.23 per cent of GDP) is more than the deficit reduction associated with one percentage point higher growth $(0.13 \text { per cent of GDP })^{18}$. Interest payments, as expected, move higher in tandem with the government's borrowing costs.

$$
\begin{aligned}
& P R D_{t}=-0.72+0.32 P R D_{t-1}-0.05 \text { D4LYNAGR }_{t}-0.08 \text { D4LYNAGR }_{t-1} \\
& \text { (2.4) (7.7) (2.9) (4.8) } \\
& +0.23 D 4 L C P I_{t}+0.004 \text { D4LOILRE_Z } Z_{t}+0.005 \text { D4LOILRE_ } Z_{t-3}+0.61 Q 22_{t} \\
& \text { (8.0) (1.2) (3.0) (3.6) } \\
& -0.06 \text { RAIN }_{t}-0.10 \text { RAIN }_{t-4}+3.46 D_{2008 Q 4}-4.12 D_{2} 2010 Q 2_{t} \\
& \text { (2.9) (6.8) (4.0) } \\
& \text { SEE }=1.2 ; \quad \text { Jstat }=0.88 ; \quad B P=0.26 \\
& I P_{t}=-1.06+0.60 I P_{t-1}+0.03 L I A B_{t-1}+0.11 G 10 Y 16 Q_{t-1}-0.41 D 2003 Q 2+0.12 D 2014 Q 1 \\
& \begin{aligned}
& (6.9) \\
+ & 0.22 D 2014 Q 2 \\
& (15.1)
\end{aligned} \\
& \bar{R}^{2}=0.98 \\
& B P=0.07^{19} ; \quad L B-Q(4)=0.89 ; \quad J B=0.16 \\
& L B-Q(4)=0.84 \\
& J B=0.52 \\
& \text { (13.4) }
\end{aligned}
$$

As regards bond yields, monetary tightening (policy rate and/or cash reserve ratio), as expected, tends to increase the yields, with the impact being substantially less than one-to-one consistent with the term structure hypothesis. An increase in statutory liquidity ratio (SLR) results in a lowering of yields, since a higher SLR increases demand for government bonds. Higher borrowing requirements tend to

\footnotetext{
${ }^{16}$ The equation is estimated using the GMM approach, with 4 lags of INTDIF, D4LEXCH, CAP, D4LVIX, and DALGDPR as instruments. Around the onset of the sub-prime crisis in the US, India experienced a spurt in capital flows, which is captured through a dummy for $2007: Q 3$.

${ }^{17}$ The equation is estimated using the GMM approach, with 4 lags each of PRD, D4LOILRE_Z, RAIN, D4LGDPW, EFF_RGAP, and 2 lags of D4LYNAGR and D4LCPI as instruments.

${ }^{18}$ A dummy for 2008:Q4 is included to account for the increase in the deficit due to the implementation of the 6th Pay Commission and the aftermath of the Lehman collapse, while a dummy for 2010:Q2 reflects the sharp reduction in the deficit on the back of large telecom auction proceeds.

${ }^{19}$ The $p$-value of the White test for the null of non-heteroscedasticity of residuals is 0.14 .
} 
harden yields. Higher investments by non-residents in government bonds soften yields. Domestic bond yields are also found to co-move with the US yields, suggesting a role for a global financial cycle.

$$
\begin{aligned}
& D G 10 Y_{t}=-0.17+0.11 D E F F_{t}+0.23 D G 10 Y_{t-2}+0.39 D C R R_{t}-0.31 D S L R_{t-1} \\
& \text { (2.1) (2.5) (3.9) (6.0) (2.6) } \\
& +0.04 G M B_{t}-0.27 \text { FII_DEBT }_{t-1}+0.002 \text { D4LOILRE }_{t}+0.22 \text { DUSG } 1_{t} \\
& \text { (2.9) (5.1) (3.6) (2.5) } \\
& -0.61 D 2002 Q 4_{t}+0.35 D 2015 Q 1_{t} \\
& \text { (15.8) (3.3) } \\
& \bar{R}^{2}=0.78 \\
& B P=0.57 ; \quad L B-Q(4)=0.79 ; \quad J B=0.65
\end{aligned}
$$

Turning to the banking sector dynamics, higher domestic economic activity is found to increase demand for real non-food bank credit, with the long-run elasticity of close to unity. Higher real interest rates and higher non-performing assets depress credit growth. Both supply and demand channels seem to be at play in the evolution of bank credit (Rajan, 2016): an increased risk aversion by banks in the face of higher NPAs and associated provisioning requirements can lead to lower credit supply, while weaker demand for credit from firms saddled with high NPAs as such firms deleverage their balance sheets can lead to lower demand. Regression estimates for NPAs (including restructured assets) indicate that higher credit growth can lead to a lagged increase in NPAs increase, while higher GDP growth helps to contain NPAs.

$$
\begin{aligned}
& D_{L R N F C}=0.36+0.22 \text { DLRNFC }_{t-1}+0.38 \text { DLRNFC }_{t-2} \\
& \text { (1.0) (1.6) (3.0) } \\
& +0.36 \text { DLYNAGR } R_{t-2}-0.62 \text { DGNPA_RA } A_{t-1}-0.32 D E F F_{-} R_{t-1}+0.03 D L O I L R_{t-4}-3.62 D 2009 Q 1_{t} \\
& \begin{array}{llll}
(2.5) & (2.5) & (1.7) & (2.0) \\
\bar{R}^{2}=0.63 ; & B P=0.35 ; & L B-Q(4)=0.77 ; & J B=0.01
\end{array}
\end{aligned}
$$

$D G N P A_{-} R A_{t}=0.90+0.06 R N F C G A P_{t-4}-0.05 D 4 L G D P R_{t-3}-0.07 D 4 L G D P R_{t-4}+0.12 D E F F_{-} R_{t-3}$

(5.7) (3.0) (4.0)

(6.1) (2.8)

$+1.21 D 2012 Q 1-0.97 D 2013 Q 1_{t}$

(11.3) (8.3)

$\bar{R}^{2}=0.45 ; \quad B P=0.79 ; \quad L B-Q(4)=0.88 ; \quad J B=0.01$

\section{Model Performance, Properties and Simulations}

\section{Model Performance}

In order to assess the interlinkages and feedback across variables and equations, all the above estimated equations are grouped in a model, with appropriate identities to capture the interactions. The performance of the baseline model is satisfactory: it is able to capture the dynamics of the data and the inter-linkages relatively well in static simulations (i.e., one-quarter ahead forecasts) over the sample period (2005-16) (Chart 1). Dynamic simulations are a relatively stricter metric to evaluate a model's performance. Such dynamic simulations ${ }^{20}$ for forecasts up to 12quarters ahead, presented in Chart 2, also suggest a satisfactory performance, with forecast errors for most variables exhibiting a self-correcting behaviour. There are

${ }^{20}$ Dynamic simulations use the actual path of policy repo rate and exchange rate. 
some exceptions, such as forecasts of core inflation, where the dynamic forecast is not able to capture the initial sharp disinflation experienced in 2014, while food inflation is estimated higher by the model.

A formal analysis of the model's dynamic forecasting performance at various horizons can be done through Theil's $U$ statistics - which compare the performance of the model variables against the benchmark of a random walk model (i.e., a no-change model) by examining ratios of their respective root mean square errors (RMSE). A value of Theil's $U$ less than one for a variable indicates that the model improves over the naïve random walk specification. On this criteria, the model again does a reasonably good job. Theil's $U$ statistics for one-, four- and eight-quarter ahead forecasts are below unity for key variables with one exception (8-quarter ahead forecast for 10-year G-sec yield) (Table 3). Moreover, for most variables, the Theil's statistic for the eight-quarter ahead forecast is less than the corresponding one-quarter ahead statistic. This indicates that the model's forecasting performance improves over the medium-term horizon and imparts a degree of confidence in the model's shortand medium-term dynamics.

\section{Model Properties}

The impact of various variables has been discussed in an individual equation framework earlier. In this sub-section, we discuss the impact and dynamics taking into account various interlinkages across equations and present results for a few important shocks. Starting with dynamics of the system to a 100 bps policy rate shock, the peak decline of about 25 bps in overall GDP takes after four quarters (Chart 3). The output gradually returns to the baseline consistent with the hump-shaped pattern in various studies. The decline in domestic demand and output reflects the effect not only of higher interest rates but also through the impact of interest rates on capital flows and exchange rate and in turn on net exports. Core inflation falls in response to lower domestic demand as well as exchange rate movements; the peak decline of around 20 bps in core inflation (and around 10 bps in overall CPI inflation) occurs 4 years after the policy shock. The impact of interest rate on output and inflation is broadly similar to Benes et al. (2016). A tighter monetary policy impacts other variables in the model through the following channels: (a) a temporary nominal appreciation of the currency on the back of higher capital flows, (b) some improvement in the current account balance in view of lower domestic activity, and (c) an initial increase in bond yields (in consonance with higher policy rate) and fiscal deficit, but a subsequent reduction in tandem with lower inflation. Given the observed high persistence (indicated by the coefficient on the lagged interest rate) in the estimated policy rate reaction function, the policy rate returns to the baseline gradually after 4 years.

Turning to dynamics in the aftermath of an exchange rate shock, the key propagation channels in the model are: Nominal exchange rate depreciation leads to higher prices of imported goods and hence higher domestic inflation, which necessitates some monetary tightening (and has a lagged negative impact on output). 
Given short-run price stickiness, nominal depreciation also translates into some real depreciation for a while (and hence a lagged positive impact on net exports and output). An initial depreciation leads to capital outflows, which puts further depreciation pressure on the currency. Reflective of these interactions, a one per cent temporary depreciation (and reversed next quarter) of the Indian rupee (vis-à-vis the US dollar) leads to a peak increase of almost 5 bps in the headline CPI inflation rate after 2-3 quarters, indicating an exchange rate pass-through coefficient of 0.05 . There is also a modest, temporary increase in GDP growth rate, and an improvement in the current account balance (Chart 4). On the other hand, a persistent one per cent depreciation to the level of the exchange rate has a higher impact on inflation, and the exchange rate pass-through coefficient is estimated at around 0.1 . One caveat is that the model does not explicitly factor in the possible headwinds from the balance sheet channel of the exchange rate discussed earlier (BIS, 2016). This channel is, however, implicitly present in the model, as the empirical regression results are driven by actual data dynamics over the sample period and can be viewed as capturing the net effect of both the trade and balance sheet channels. It would, however, be useful to incorporate such an effect explicitly in future research for a better and robust understanding of the dynamics.

\section{Model Simulations: Alternative Monetary Rules}

In view of the earlier noted estimation challenges from the regime shift towards a CPI-based framework, this section assesses model dynamics using monetary policy reaction functions employed in two recent studies -Benes et al. (2016) (dubbed "QPM" rule in the discussion below) and Patra et al. (2017) (dubbed "PKG" rule). The reaction function in Benes et al. responds both to deviations of headline and core inflation from the policy target, with more aggressive response to core inflation. Patra et al. (2017) endeavour for an "optimal" policy rule in a framework that minimises the central bank's quadratic loss-function framework, i.e., minimises deviations of output and inflation from policy objectives. The optimal rule in PKG puts a substantially lesser weight on interest rate smoothing compared to the literature. Moreover, the ratio of weight on output gap to inflation gap as well as the individual coefficients on these two terms is also notably higher than the standard Taylor rule. The "estimated rule" (i.e., the monetary policy reaction estimated earlier on in this section) is reproduced below along with the QPM and PKG rule equations for comparison (in the equations below, 'rstar' is nominal neutral policy rate, which is taken as 6 per cent purely for a comparative analysis of the three rules; and, DALCPIGAP and DLACPIEXFFGAP are deviations of actual headline and core inflation from the target $)^{21}$.

\footnotetext{
${ }^{21}$ Amongst the various possible candidate versions considered in Patra et al. (2017), we consider the scenario which minimises the objective loss function in Table 3 (page 362) of their paper, i.e., the rule with coefficients $0.40,1.51$ and 1.77 on lagged interest rate, output gap and inflation gap.
} 
$\mathrm{EFF}=0.88^{\star} \mathrm{EFFt}_{\mathrm{t}-1}+(1-0.88)^{*}\left[\left(\right.\right.$ rstar $+1.36^{*}$ DALCPIGAPt $+1+0.78^{*}$ GDPRGAPt $+1^{2}+0.80^{*}$ FEDTARGET $\left.)\right]$

(Estimated Rule)

$\mathrm{EFF}=0.85^{\star} \mathrm{EFF}_{\mathrm{t}-1}+(1-0.85)^{\star}\left(\mathrm{rstar}_{+}+0.5^{\star} \mathrm{DALCPIGAP}_{\mathrm{t}+3}+2.5^{\star}\right.$ DALCPIEXFFGAPt $\left._{t+3}+0.5^{\star} \mathrm{GDPRGAP}\right)$

(QPM Rule)

$\mathrm{EFF}=0.4^{*} \mathrm{EFFt}-1+(1-0.4)^{*}\left(\mathrm{rstar}+2.95^{*} \mathrm{DALCPIGAP}+2.52^{*} \mathrm{GDPRGAP}\right)$

(PKG Rule)

We restrict the comparative performance of the three rules to a few policy relevant shocks. Starting with the responses to an interest rate shock, an initial interest rate increase of 100 bps leads to lesser impact on both output and inflation in the PKG rule model compared to other models (Chart 5 ): the key driving force for this result is that the interest rate returns relatively quickly to the baseline in the PKG set up (given its lower persistence) and hence the magnitude of the impact on output and inflation is lower than the other rules. This outcome is consistent with a priori restriction that Patra et al. (2017) impose on their optimal rule: minimise deviations of output and inflation from the objectives. The comparative dynamics therefore suggest that a desired disinflation goal would need a higher initial tightening in the PKG rule compared to the other two rules. The impact on inflation and output is more persistent as well as protracted in the "estimated" rule. ${ }^{22}$

Turning to a shock to core inflation, it attracts the strongest interest rate response under the PKG rule, given its high weight on the overall inflation gap. Hence, core inflation as well as overall inflation and output gap return relatively quickly to the baseline relative to the two other rules (Chart 6). Real interest rate turns positive quickly in the PKG and QPM rules, whereas it remains in the negative territory for a considerable period of time in the estimated rule. A corollary of these dynamics is somewhat larger negative output gap in the PKG and QPM rules.

Moving to comparative dynamics in response to a demand shock, the initial interest rate response is more aggressive in the PKG rule (since it puts more weight on output gap compared to other rules), while the path is more persistent under the QPM rule. Headline inflation returns to the baseline faster in the PKG and the QPM rules vis-à-vis the "estimated" rule (Chart 7).

Overall, all the three rules considered in this paper have the desirable feature of stabilising inflation as well as output, but given their design features highlight the issue of policy preferences and policy trade-offs. Of course, no central bank or its monetary policy committee members follow monetary policy rules mechanically, since these are "too simple, and ignore important complexities" (Yellen, 2015). There is also a view that simple rules are frequently more robust across models than fully optimal rules (Taylor and Williams, 2011). Moreover, as Goodfriend and King (2016, page. 91)

\footnotetext{
22 This comparative exercise has been attempted by using alternative monetary policy rules, while keeping the remaining model structure. The comparative performance of the rules considered here could differ across alternative models of the economy.
} 
caution: "Monetary policy cannot be reduced to the automatic application of one specific model. Choosing the so-called optimal policy in a misspecified model can lead to serious mistakes. Alternative "models" of the economy must be considered and judgement used".

\section{Concluding Observations}

With the introduction of flexible inflation targeting in India beginning 2014 and the switch to consumer price index inflation as the nominal anchor for monetary policy, a renewed look at transmission dynamics assumes importance and this was the key objective of this paper. The paper undertook this exercise in a new Keynesian framework, with the model adapted to Indian conditions. Moreover, unlike most of the existing studies, the paper assessed transmission dynamics in a broader framework, by augmenting the monetary block with external, fiscal and banking sector blocks to capture feedback and interactions amongst key macroeconomic variables and policies.

The paper's empirical analysis indicates that monetary policy is effective in containing demand and inflationary pressures, and the effects are modest consistent with the existing cross-country and Indian evidence. A tight monetary policy and low inflation is also found to have a stabilising impact on fiscal dynamics. The model simulations suggest a satisfactory performance, and the forecasting performance generally improves as the forecast horizon is extended from one quarter to eight quarters. The paper also assessed transmission dynamics across a few alternative monetary policy rules to examine the role of policy preferences and their implications for output and inflation dynamics and policy trade-offs.

The modelling approach pursued in the paper can be strengthened further in future work. For instance, first, output and demand dynamics can be analysed from the expenditure side of GDP (private consumption, government consumption, investment and net exports) in addition to the sectoral side (industry and services) approach in this paper. Second, bank credit growth has been modelled as a reduced form equation, capturing both demand and supply factors. It might be more useful to estimate separate equations for supply of bank credit and demand for bank credit in view of the recent stress in the banking system.

The results in the paper are subject to the caveat of being model specific, as no one model captures all the relevant features of an economy or consistently beats other forecasts (Kent, 2016). Although models are useful in putting together consistent quantitative forecasts, they are based on strong assumptions and can act as no more than a starting point for a discussion of the challenges facing monetary policy at any particular juncture (Goodfriend and King, 2016). Moreover, the magnitude of the responses to various shocks and the associated lags reflect averages over the sample period, and the actual dynamics would depend upon the specific situation. While the paper's model assumes a linear structure, the actual effects could be both asymmetric and non-linear, which are best examined in an individual equation framework. 
Large shocks can lead to a deterioration in a model's forecasting performance, as has been observed to be the case for major central banks in the Great Recession episode, and an ex-post analysis suggests that forecasting improvements are possible from a better incorporation of financial sector variables, including high-frequency data (Alessi et al., 2014). In view of the ongoing structural reforms, deregulation and opening up of the Indian economy, as well as ongoing initiatives to improve the efficacy of monetary transmission, the transmission dynamics can be expected to evolve over time. Finally, an additional caveat in interpreting this paper's analysis is the monetary regime switch with the introduction of flexible inflation targeting, introduced only in 2014: its implications for inflation expectations and monetary transmission would need to be re-assessed as more data become available and also across alternative modelling approaches.

\section{References}

Acharya, V.V., T. Eisert, C. Eufinger, and C.W. Hirsch (2016), "Whatever it Takes: The Real Effects of Unconventional Monetary Policy", Working Paper, New York University Stern School of Business.

Acharya, Viral V. (2017), "Monetary Transmission in India: Why is it Important and Why hasn't it Worked Well?", Reserve Bank of India Bulletin, Vol. LXXI, No. 12, pp.716.

Ahmed, Swarnali, Maximiliano Appendino and Michele Ruta (2015), "Global Value Chains and the Exchange Rate Elasticity of Exports", Working Paper No. WP/15/252, International Monetary Fund.

Alessi, Lucia, Eric Ghysels, Luca Onorante, Richard Peach \& Simon Potter (2014), "Central Bank Macroeconomic Forecasting during the Global Financial Crisis: The European Central Bank and Federal Reserve Bank of New York Experiences", Journal of Business \& Economic Statistics, Vol. 32 (4), pp. 483-500,

Anzuini, Alessio and Aviram Levy. (2007) "Monetary Policy Shocks in the New EU Members: A VAR Approach." Applied Economics, 39, 1147-61.

Ball, Laurence and Sandeep Mazumder (2015), "A Phillips Curve with Anchored Expectations and Short-Term Unemployment", Working Paper WP/15/39, International Monetary Fund.

Banerjee, Shesadri, Harendra Behera, Sanjib Bordoloi and Rakesh Kumar (2018), "'Role of Financial Frictions in Monetary Policy Transmission in India", Development Research Group Study 44, Reserve Bank of India.

Bank for International Settlements (2016), 86 ${ }^{\text {th }}$ Annual Report.

Barakchian, S. Mahdi and Christopher Crowe (2013), "Monetary Policy Matters: Evidence from New Shocks Data", Journal of Monetary Economics, Vol. 60, pp. 950966.

Bardsen, Gunnar, Ard den Reijer, Patrik Jonasson and Ragnar Nymoen (2011), "MOSES: Model of Swedish Economic Studies", Working Paper Series No. 249, Sveriges Riksbank. 
Behera, Harendra, Garima Wahi and Muneesh Kapur (2017), "Phillips Curve Relationship in India: Evidence from State-level Analysis", Working Paper WPS (DEPR) 08/2017, Reserve Bank of India, July 2017

Behera, Harendra, Sitikantha Pattanaik and Rajesh Kavediya (2015), "Natural Interest Rate: Assessing the Stance of India's Monetary Policy under Uncertainty", Working Paper 5, Reserve Bank of India.

Baumeister, Christiane and Lutz Kilian (2016), "Lower Oil Prices and the U.S. Economy: Is This Time Different?" Brookings Papers on Economic Activity, Fall 2016, pp.287-357.

Benes, J., K. Clinton, A. George, J. John, O. Kamenik, D. Laxton, P. Mitra, G.V. Nadhanael, H. Wang and F. Zhang (2016). "Inflation Forecast Targeting for India: An Outline of the Analytical Framework" (Mimeo).

Bhoi, Barendra Kumar, Arghya Mitra, Jang Bahadur Singh and Gangadaran Sivaramakrishnan (2016), "Effectiveness of Alternative Channels of Monetary Policy Transmission: Some Evidence for India", Mimeo

Blanchard, Olivier, Eugenio Cerutti, and Lawrence Summers (2015), "Inflation and Activity: Two Explorations and their Monetary Policy Implications", Working Paper WP/15/230, International Monetary Fund.

Blanchard, Olivier (2016), "The Phillips Curve: Back to the '60s?", American Economic Review: Papers \& Proceedings, Vol. 106(5), pp. 31-34

--- (2018), "On the Future of Macroeconomic Models", Oxford Review of Economic Policy, Vol. 34 (1-2), pp. 43-54

Boivin, Jean, Michael Kiley and Frederic Mishkin (2011), "How Has the Monetary Transmission Mechanism Evolved Over Time?" pp. 369-422, in Benjamin Friedman and Michael Woodford (ed.), "Handbook of Monetary Economics", Volume 3A, Elsevier B.V.

Borio, Claudio, and Haibin Zhu (2008), "Capital Regulation, Risk-taking and Monetary Policy: A Missing Link in the Transmission Mechanism?”, Working Paper 268, Bank for International Settlements.

Catão, Luis, Douglas Laxton, and Adrian Pagan (2008), Monetary Transmission in an Emerging Targeter: The Case of Brazil, Working Paper WP/08/191, International Monetary Fund.

Christiano, Lawrence J., Martin Eichenbaum, and Charles L. Evans (1999), ““Monetary Policy Shocks: What Have We Learned and to What End?" In Handbook of Macroeconomics, vol. 1A, edited by John B. Taylor and Michael Woodford. Amsterdam: Elsevier Sci.

Clarida, Richard, Jordi Gali and Mark Gertler (1998), "Monetary Policy Rules in Practice: Some International Evidence", European Economic Review, Vol.42, pp.1033-1067.

---- (1999), "The science of Monetary Policy: A New Keynesian Perspective", Journal of Economic Literature, Vol. 37 (4), December, pp. 1661-1707.

---- (2000), "Monetary Policy Rules and Macroeconomic Stability: Evidence and Some Theory", Quarterly Journal of Economics, February, pp.147-180. 
Coibion, Olivier (2012), "Are the Effects of Monetary Policy Shocks Big or Small?", American Economic Journal: Macroeconomics, Vol. 4(2), pp. 1-32

Coibion, Olivier and Yuriy Gorodnichenko (2012), "Why Are Target Interest Rate Changes so Persistent?", American Economic Journal: Macroeconomics, Vol. 4(4), pp. 126-162

--- (2015): "Is the Phillips Curve Alive and Well After All? Inflation Expectations and the Missing Disinflation", American Economic Journal: Macroeconomics, Vol 7(1), pp. 197-232

Cloyne, James and Patrick Hürtgen (2015), "The Macroeconomic Effects of Monetary Policy: A New Measure for the United Kingdom”, Working Paper 493, Bank of England.

Dahlhaus, Tatjana (2017), "Conventional Monetary Policy Transmission during Financial Crises: An Empirical Analysis", Journal of Applied Econometrics, Vol. 32(2), pp.401-421.

Dell'Ariccia, Giovanni, Luc Laeven and Gustavo Suarez (2016), "Bank Leverage and Monetary Policy's Risk-taking Channel: Evidence from the United States”, Working Paper 1903, European Central Bank.

Disyatat, Piti and Pinnarat Vongsinsirikul (2003), "Monetary Policy and the Transmission Mechanism in Thailand", Journal of Asian Economics, Vol. 14 (3), pp. 389-418

Dhal, Sarat (2012), "Industry Effects of Monetary Transmission Mechanism in India: An Empirical Analysis of Use-based Industries", Reserve Bank of India Occasional Papers, Vol. 32(2), pp. 39-79.

Els, Peter van, Alberto Locarno, Benoît Mojon, and Julian Morgan (2003), "New Macroeconomic Evidence on Monetary Policy Transmission in the Euro Area", Journal of the European Economic Association, Vol. 1, No. 2/3, April-May, pp. 720-730.

Fischer, Stanley (2015), "The Transmission of Exchange Rate Changes to Output and Inflation", available

at

http://www.federalreserve.gov/newsevents/speech/fischer20151112a.htm

Forbes, Kristin (2015), "Much Ado about Something Important: How do Exchange

Rate Movements Affect Inflation?", available at

http://www.bankofengland.co.uk/publications/Pages/speeches/2015/839.aspx

Fukunaga, Ichiro, Naoko Hara, Satoko Kojima, Yoicho Ueno and Shunichi Yoneyama (2011), "The Quarterly Japanese Economic Model (Q-JEM): 2011 Version”, Working Paper No.11-E-11, Bank of Japan.

Gali, Jordi (2008), Monetary Policy, Inflation, and the Business Cycle: An Introduction to the New Keynesian Framework, Princeton University Press, Princeton, New Jersey.

Gali, Jordi and Mark Gertler (1999), "Inflation Dynamics: A Structural Econometric Analysis", Journal of Monetary Economics, Vol. 44, pp. 195-222.

Gali, Jordi, Mark Gertler and David Lopez-Salido (2005), "Robustness of the Estimates of the Hybrid New Keynesian Phillips Curve", Journal of Monetary Economics, Vol.52(6), pp. 1107-18.

García, Carlos, Pablo García, Igal Magendzo and Jorge E. Restrepo (2005), "The Monetary Transmission Mechanism in Chile: A Medium-Sized Macroeconometric 
Model" in Rómulo Chumacero and Klaus Schmidt-Hebbel (ed.), "General Equilibrium Models for the Chilean Economy", Central Bank of Chile.

Gertler, Mark and Peter Karadi (2015), "Monetary Policy Surprises, Credit Costs, and Economic Activity," American Economic Journal: Macroeconomics, Vol. 7(1), pp. 4476.

Gervais, Olivier and Marc-André Gosselin (2014), "Analyzing and Forecasting the Canadian Economy through the LENS Model", Technical Report 102, Bank of Canada.

Goodfriend, Marvin and Mervyn King (2016), Review of the Riksbank's Monetary Policy 2010-2015, available at http://data.riksdagen.se/dokument/RFR-201516RFR7.pdf

Goodhart, Charles and Boris Hofmann (2005), "The IS Curve and Transmission of Monetary Policy: Is there a Puzzle?", Applied Economics, Vol.37, pp.29-36.

Gopinath, Gita (2015), "The International Price System", Working Paper 21646, National Bureau of Economic Research

Gordon, Robert (2011), "The History of the Phillips Curve: Consensus and Bifurcation", Economica, Vo. 78, January, pp.10-50.

--- (2013), "The Phillips Curve is Alive and Well: Inflation and the NAIRU during the Slow Recovery, Consensus and Bifurcation", Working Paper 19390, National Bureau of Economic Research.

Hammersland, Roger and Cathrine Bolstad Traee (2012), "The Financial Accelerator and the Real Economy: A Small Macroeconometric Model for Norway with Financial Frictions", Staff Memo No. 2, Norges Bank.

Havranek, Tomas and Marek Rusnak (2013), "Transmission Lags of Monetary Policy: A Meta-Analysis", International Journal of Central Banking, Vol. 9(4), pp. 39-75

International Monetary Fund (2015a), "Global Implications of Lower Oil Prices", Staff Discussion Note, SDN/1515

---- (2015b), "Exchange Rates and Trade Flows: Disconnected?" (Chapter 3), World Economic Outlook, October

--- (2016a), World Economic Outlook, April

---- (2016b), "Exchange Rate Pass-through in Latin America", Regional Economic Outlook: Western Hemisphere, April

Kapur, Muneesh (2013), "Revisiting the Phillips curve for India and Inflation Forecasting", Journal of Asian Economics, Vol. 25, pp. 17-27.

Kapur, Muneesh and Michael Patra (2000), "The Price of Low Inflation", RBI Occasional Papers, Volume 21 (2 and 3), Reserve Bank of India, pp. 191-233.

Kapur, Muneesh and Rakesh Mohan (2014), "India's Recent Macroeconomic Performance: An Assessment and Way Forward", Working Paper WP/14/68, International Monetary Fund.

Karapetyan, Artashes (2016),"The Risk-taking Channel of Monetary Policy in Norway", Working Paper 5, Norges Bank

Kent, Christopher (2016), Economic Forecasting at the Reserve Bank of Australia, available at http://www.rba.gov.au/speeches/2016/sp-ag-2016-04-06.html 
Khundrakpam, Jeevan Kumar (2008), "Have Economic Reforms Affected Exchange Rate Pass-Through to Prices in India", Economic and Political Weekly, Vol.43 (16), April 19, 2008, pp.71-79.

--- (2012), "Estimating Impacts of Monetary Policy on Aggregate Demand in India", Working Paper 18, Reserve Bank of India.

Kiley, Michael (2014), "The Aggregate Demand Effects of Short- and Long-Term Interest Rates", International Journal of Central Banking, Vol. 10(4), pp. 69-104.

Lahiri, Amartya and Urjit Patel (2016), "Challenges of Effective Monetary Policy in Emerging Economies", Working Paper 1, Reserve Bank of India.

Lees, Kirdan (2016), "Assessing Forecast Performance", Reserve Bank of New Zealand Bulletin, Vol. 79 (10).

Lewis, John (2016), "What can Big Data tell us about the Pass-through of Big Exchange Rate Changes?", Working Paper 579, Bank of England.

Li, Bin Grace, Stephen O'Connell, Christopher Adam, Andrew Berg, and Peter Montiel (2016), "VAR meets DSGE: Uncovering the Monetary Transmission Mechanism in Low-Income Countries", Working Paper WP/16/90, International Monetary Fund.

Mallick, Sushanta and Ricardo Sousa (2012), "Real Effects of Monetary Policy in Large Emerging Economies", Macroeconomic Dynamics, Vol. 16 (Supplement 2), pp. 190-212

Mavroeidis, Sophocles, Mikkel Plagborg-Moller, and James Stock (2014), "Empirical Evidence on Inflation Expectations in the New Keynesian Phillips Curve", Journal of Economic Literature, Vol. 52(1), pp. 124-188.

Mishra, Prachi, Peter Montiel, and Rajeswari Sengupta (2016), "Monetary Transmission in Developing Countries: Evidence from India", Working Paper 8, Indira Gandhi Institute of Development Research.

Mohan, Rakesh (2009), "Monetary Policy in a Globalised Economy", Oxford University Press, New Delhi.

Mohanty, Deepak (2012), "Evidence on Interest Rate Channel of Monetary Policy Transmission in India", Paper Presented at RBl's Second International Research Conference, $\quad$ February 1-2, 2012, Mumbai (http://sirc.rbi.org.in/downloads/SIRCPaper.pdf)

Olsen, Oystein (2011), "Monetary Policy and Inter-relationships in the Norwegian Economy", Address at the Centre for Monetary Economics, September 5, available at: http://www.norges-bank.no/en/about/published/speeches/2011/cme-lecture/

Paez-Farrell, Juan (2009), "Monetary Policy Rules in Theory and in Practice: Evidence from the UK and the US", Applied Economics, Vol. 41(16), pp. 2037 -2046

Patra, Michael and Muneesh Kapur (2012a), "A Monetary Policy Model for India", Macroeconomics and Finance in Emerging Market Economies, Vol. 5(1), March, pp. 16-39.

Patra, Michael and Muneesh Kapur (2012b), "Alternative Monetary Policy Rules for India", Working Paper WP/12/118, International Monetary Fund.

Patra, Michael, Jeevan Khundrakpam, Asish George (2014), "Post-Global Crisis Inflation Dynamics in India: What has Changed?", in Shah, Shekhar, Barry Bosworth 
and Arvind Panagariya (ed), India Policy Forum 2013-14, Vol. 10, Sage Publications, New Delhi, pp. 117-191

Patra, Michael, Jeevan Khundrakpam, and S. Gangadaran (2017), "The Quest for Optimal Monetary Policy Rules in India”, Journal of Policy Modelling, Vol. 39, pp. 349370.

Patra, Michael, Jeevan Khundrakpam, and Joice John (2018), "Non-Linear, Asymmetric and Time-Varying Exchange Rate Pass-Through: Recent Evidence from India", Working Paper WPS (DEPR): 02, Reserve Bank of India.

Pruski, Jerzy and Piotr Szpunar (2008), "The Monetary Transmission Mechanism In Poland" in "Transmission Mechanisms For Monetary Policy In Emerging Market Economies", BIS Papers No. 35, Bank for International Settlements.

Ramey, Valerie (2016), "Macroeconomic Shocks and their Propagation", Working Paper 21978, National Bureau of Economic Research.

Rajan, Raghuram (2016), "Resolving Stress in the Banking System", Speech at ASSOCHAM - Interactive Meet with Industry \& Trade, June 22, available at https://rbidocs.rbi.org.in/rdocs/Speeches

Reserve Bank of India (2004), Report on Currency and Finance 2003-04.

--- (2013), "Real Interest Rate impact on Investment and Growth - What the Empirical Evidence for India Suggests?",

--- (2014), Report of the Expert Committee to Revise and Strengthen the Monetary Policy Framework (Chairman: Urjit R. Patel)

--- (2016), Monetary Policy Report, October

--- (2017), Report of the Internal Study Group to Review the Working of the Marginal Cost of Funds Based Lending Rate System (Chairman: Janak Raj),

Romer, Christina and David Romer (2004), "A New Measure of Monetary Policy Shocks: Derivation and Implications," American Economic Review, Vol. 94(4), pp. 1055-84.

Rudd, J. and Whelan (2007), "Modelling Inflation Dynamics: A Critical Review of Recent Research", Journal of Money, Credit and Banking, Supplement to Vol.39(1), pp.155-170.

Rudebusch, Glenn and Lars Svensson (1999), "Policy Rules for Inflation Targeting" in J.B. Taylor (ed.), "Monetary Policy Rules", University of Chicago Press.

Rudebusch, Glenn (2006), "Monetary Policy Inertia: Fact or Fiction?", International Journal of Central Banking, Vol. 2(4), pp. 85-135.

Rusnak, Marek, Tomas Havranek, and Roman Horvath (2011), "How to Solve the Price Puzzle? A Meta-Analysis", Journal of Money, Credit and Banking, Vol. 45(1), pp. 37-70.

Salunkhe, Bhavesh and Anuradha Patnaik (2018), "The IS Curve and Monetary Policy Transmission in India: A New Keynesian Perspective", Margin - The Journal of Applied Economic Research, Vol.12(1), pp:41-66 
Sidaoui, José J. and Manuel Ramos-Francia (2008), "The Monetary Transmission Mechanism in Mexico: Recent Developments" in "Transmission Mechanisms For Monetary Policy In Emerging Market Economies", BIS Papers No. 35, Bank for International Settlements.

Singh, Bhupal (2012), "How Important is the Stock Market Wealth Effect on Consumption in India?", Empirical Economics, Vol. 42, pp. 915-927

Sonna, Thangzason, Himanshu Joshi, Alice Sebastian and Upasana Sharma (2014), "Analytics of Food Inflation in India", Working Paper 10, Reserve Bank of India

Stein, Jeremy and Adi Sunderam (2016), "The Fed, the Bond Market, and Gradualism in Monetary Policy", available at http://scholar.harvard.edu/files/stein/files/gradualism february 2016 final.pdf?m=14 $\underline{55034472}$

Taylor, J. B. (1993) "Discretion versus Rules in Practice", Carnegie Rochester Series on Public Policy, Vol. 39, pp. 195-214.

Taylor, John and John Williams (2011), "Simple and Robust Rules for Monetary Policy", Handbook of Monetary Economics, Volume 3B, Elsevier, 829-859.

Ulvedal, Pål Bergset and Nikka Husom Vonen (2016), "Pass-through from Exchange Rate Movements to Consumer Prices", Staff Memo 3, Norges Bank.

Vonnák, Balázs (2008), "The Hungarian Monetary Transmission Mechanism: An Assessment" in "Transmission Mechanisms For Monetary Policy in Emerging Market Economies", BIS Papers No. 35, Bank for International Settlements.

Wahi, Garima and Muneesh Kapur (2018), "Economic Activity and its Determinants: A Panel Analysis of Indian States", Working Paper WPS (DEPR) 04/2018, Reserve Bank of India

Walsh, Carl (2010), "Monetary Theory and Policy", MIT Press, Cambridge, Massachusetts.

Willis, Jonathan and Guangye Cao (2015), "Has the U.S. Economy Become Less Interest Rate Sensitive?", Federal Reserve Bank Of Kansas City, Economic Review, Second Quarter, pp. 5-36.

Woodford, Michael (2003), "Interest and Prices: Foundations of a Theory of Monetary Policy”, Princeton University Press, Princeton.

Wren-Lewis, Simon (2018), "Ending the Microfoundations Hegemony", Oxford Review of Economic Policy, Vol. 34 (1-2), pp. 55-69

Yellen, Janet (2015), "Normalizing Monetary Policy: Prospects and Perspectives", https://www.federalreserve.gov/newsevents/speech/yellen20150327a.htm 


\begin{tabular}{|c|c|}
\hline \multicolumn{2}{|r|}{ Table 1: List of Variables } \\
\hline Variable Name & Explanation \\
\hline $\mathrm{CAB}$ & Current account balance (\% of GDP) \\
\hline CAP & Capital account balance (\% of GDP) \\
\hline D4LCPIEXFF & Consumer price index inflation, excluding food and fuel (q/q,saar) \\
\hline D4LCPIEXFF4Q & 4-quarter average of D4LCPIEXFF \\
\hline D4LCPIFOOD & Consumer price index inflation, food group (q/q,saar) \\
\hline D4LCPIFUEL & Consumer price index inflation, fuel group (q/q,saar) \\
\hline D4LCPIFUEL4Q & 4-quarter average of D4LCPIFUEL \\
\hline D4LCPI & Consumer price index inflation (q/q,saar) \\
\hline D4LEXCH & Exchange rate (Indian rupee per US \$) ( $q / q$ ar change) \\
\hline D4LGDPR & Real GDP (q/q saar change) \\
\hline D4LMSPC & Minimum support prices ( $q / q$ saar change) \\
\hline DLRNFC & Real non-food bank credit (q/q saar change) \\
\hline D4LOIL & International crude oil prices (in US $\$$ terms) ( $q / q$ ar change) \\
\hline D4LOILR & International crude oil prices (real) (q/q ar change) \\
\hline D4LOILRE & International crude oil price (in rupee terms) ( $\mathrm{q} / \mathrm{q}$ ar change) \\
\hline D4LWEXPR & World real exports (q/q saar change) \\
\hline D4LWFOODRE & International food prices (in rupee terms) (q/q saar change) \\
\hline D4LYIND & Industrial sector real GDP ( $\mathrm{q} / \mathrm{q}$ saar change) \\
\hline D4LYNAGR & $\begin{array}{l}\text { Real GDP excluding agriculture and 'community, social and personal } \\
\text { services' ( } q / q \text { saar change) }\end{array}$ \\
\hline DALCPIGAP & Deviation of CPI inflation from target \\
\hline DALGDPR & Real GDP (y/y change) \\
\hline DALOILAVGRE & International crude oil price (in rupee terms) (y/y change) \\
\hline DALREER & Real effective exchange rate (y/y change) \\
\hline DALWPIGAP & Deviation of wholesale price index (WPI) inflation from target \\
\hline DCRR & Cash reserve ratio ( $q / q$ change) \\
\hline DEFF & Effective policy rate ( $q / q$ change) \\
\hline DEFF_R & $\begin{array}{l}\text { Effective policy rate, real (= Effective policy rate (nominal) less 4-quarter } \\
\text { average of CPI inflation) (q/q change) }\end{array}$ \\
\hline DG10Y & Yield on 10-year central government securities ( $q / q$ change) \\
\hline DGNPA_RA & $\begin{array}{l}\text { Gross non-performing and restructured assets ( } \% \text { of advances) of } \\
\text { commercial banks ( } q / q \text { change) }\end{array}$ \\
\hline DLRP & Ratio of Indian CPI to the US CPI (q/q change) \\
\hline DLEXCH & Exchange rate (Indian rupee per US \$) (q/q change) \\
\hline DLVIX & VIX (Chicago Board Options Exchange Volatility Index) (q/q change) \\
\hline DSLR & Statutory liquidity ratio ( $q / q$ change) \\
\hline DLYNAGR & $\begin{array}{l}\text { Real GDP excluding agriculture and 'community, social and personal } \\
\text { services' (q/q sa change) }\end{array}$ \\
\hline DUSG1 & Yield on one-year G-sec of the US (q/q change) \\
\hline EFF & Effective policy rate, nominal \\
\hline EFF_RGAP & Effective policy rate, real, gap \\
\hline FEDTARGET & Fed funds target rate \\
\hline FII_DEBT & Net foreign portfolio investments in debt (\% of GDP) \\
\hline G10Y16Q & Yield on 10-year central government securities (16-quarter average) \\
\hline GDPRGAP & Real GDP, gap \\
\hline GMB & Central government market borrowings (\% of GDP) \\
\hline INTDIF & $\begin{array}{l}\text { Difference between yields on 10-year government securities in India and } \\
\text { the US }\end{array}$ \\
\hline IP & Central government interest payments (\% of GDP) \\
\hline Q2 & $\begin{array}{l}\text { Dummy variable for second quarter of each financial year (= } 1 \text { if it is Q2, } 0 \\
\text { otherwise) }\end{array}$ \\
\hline
\end{tabular}




\begin{tabular}{|c|c|}
\hline RMINOILGAP & Real domestic WPI minerals oil price index, gap \\
\hline RNFCGAP & Real non-food bank credit, gap \\
\hline RAIN & Deviation of rainfall from its normal level \\
\hline PRD & $\begin{array}{l}\text { Central government's primary revenue deficit excluding interest payments } \\
(\% \text { of GDP) }\end{array}$ \\
\hline REERGAP & Real effective exchange rate, gap \\
\hline LIAB & Central government's liabilities (\% of GDP) \\
\hline WEXPGAP & World real exports, gap \\
\hline YAGRIGAP & Agricultural sector real GDP, gap \\
\hline YINDGAP & Industrial sector real GDP, gap \\
\hline YSERVGAP & Services sector real GDP excluding social and personal services', gap \\
\hline $\begin{array}{l}\text { Note: } \\
\text { q/q = quarter } \\
\text { seasonally ad } \\
\text { Real variables } \\
\text { inflation in cas } \\
\text { Prefix L indice } \\
\text { log-difference } \\
\text { terms; Prefix } \\
\text { growth in per } \\
\text { Suffix GAP in } \\
\text { actual series } \\
\text { inflation from } \\
\text { Point dummy } \\
\text { takes value } 1 \\
\text { the period ] }\end{array}$ & $\begin{array}{l}\text { quarter change; } y / y=\text { year-on-year change; ar = annualised rate; saar = } \\
\text { ed annualised rate. } \\
\text { ve been obtained by deflating nominal variables with } \mathrm{CPI} \text { index (or, with } \mathrm{CPI} \\
\text { interest rate). } \\
\text { natural log of a variable; Prefix } \mathrm{D}=\text { first difference of a variable; Prefix } \mathrm{DL}= \\
\text { Itiplied by } 100 \text { ) of a variable, i.e., quarter-on-quarter }(\mathrm{q} / \mathrm{q} \text { ) growth in per cent } \\
=\mathrm{q} / \mathrm{q} \text {, annualized, growth in per cent terms; Prefix } \mathrm{DAL}=\text { year-on-year (y/y) } \\
\text { terms. } \\
\text { tes the variable is in gap from, defined as log-difference (multiplied by } 100 \text { ) of } \\
\text { its Hodrick-Prescott (HP) filtered series. DALCPIGAP is the deviation of CPI } \\
\text { arget. } \\
\text { ables are denoted by ' } \mathrm{D} \text { ' followed by the specific quarter of a year for which it } \\
\text { erwise } 0 \text {. [e.g. D2002Q2 takes } 1 \text { for second quarter of } 2002 \text { and } 0 \text { for rest of }\end{array}$ \\
\hline
\end{tabular}


Table 2: Unit Root Results

\begin{tabular}{|c|c|c|c|c|c|c|}
\hline \multirow[b]{4}{*}{ Variable } & \multirow{2}{*}{\multicolumn{4}{|c|}{ Table 2: Unit Root Results }} & \multirow{2}{*}{\multicolumn{2}{|c|}{$\begin{array}{c}\text { Phillips-Perron (PP) } \\
\text { tests }\end{array}$}} \\
\hline & & & & & & \\
\hline & \multicolumn{2}{|c|}{ With constant } & \multicolumn{2}{|c|}{$\begin{array}{l}\text { With constant and } \\
\text { trend }\end{array}$} & \multirow{2}{*}{\begin{tabular}{r|}
$\begin{array}{l}\text { With } \\
\text { constant }\end{array}$ \\
t-stat \\
\end{tabular}} & \multirow{2}{*}{\begin{tabular}{|r|}
$\begin{array}{l}\text { With } \\
\text { constant } \\
\text { and trend } \\
\text { t-stat }\end{array}$ \\
\end{tabular}} \\
\hline & Lags & t-stat & Lags & t-stat & & \\
\hline CAB & 0 & -2.70 & 0 & -3.03 & -2.76 & -3.12 \\
\hline CAP & 0 & -4.25 & 0 & -4.19 & -4.36 & -4.31 \\
\hline D4LCPIEXFF & 1 & -2.89 & 1 & -2.96 & -6.13 & -6.34 \\
\hline D4LCPIEXFF4Q & 0 & -1.40 & 0 & -1.30 & -1.56 & -1.53 \\
\hline D4LCPIFOOD & 0 & -6.12 & 0 & -6.43 & -6.22 & -6.53 \\
\hline D4LCPIFUEL & 0 & -5.14 & 0 & -5.08 & -5.13 & -5.12 \\
\hline D4LCPIFUEL4Q & 4 & -1.56 & 4 & -1.58 & -2.61 & -2.61 \\
\hline D4LCPI & 0 & -5.50 & 0 & -5.81 & -5.69 & -6.02 \\
\hline D4LEXCH & 0 & -6.03 & 0 & -6.20 & -5.97 & -6.23 \\
\hline D4LGDPR & 0 & -8.59 & 0 & -8.52 & -8.57 & -8.56 \\
\hline D4LMSPC & 2 & -2.12 & 2 & -2.13 & -3.47 & -3.50 \\
\hline DLRNFC & 1 & -1.85 & 1 & -2.73 & -3.45 & -4.41 \\
\hline D4LOIL & 0 & -6.14 & 0 & -6.26 & -5.59 & -5.92 \\
\hline D4LOILR & 0 & -5.67 & 0 & -5.86 & -5.22 & -5.62 \\
\hline D4LOILRE & 0 & -6.42 & 0 & -6.49 & -5.87 & -6.14 \\
\hline D4LWEXPR & 0 & -5.07 & 0 & -5.08 & -4.80 & -4.89 \\
\hline D4LWFOODRE & 0 & -5.79 & 0 & -5.74 & -5.65 & -5.67 \\
\hline D4LYIND & 0 & -8.46 & 0 & -8.44 & -9.32 & -9.32 \\
\hline D4LYNAGR & 0 & -8.04 & 0 & -7.99 & -7.72 & -7.73 \\
\hline DALGDPR & 0 & -4.13 & 0 & -4.04 & -3.67 & -3.66 \\
\hline DALOILAVGRE & 1 & -4.26 & 1 & -4.55 & -2.70 & -2.86 \\
\hline DALREER & 5 & -3.25 & 5 & -3.29 & -3.28 & -3.30 \\
\hline DALWPIGAP & 1 & -3.12 & 1 & -3.26 & -1.69 & -1.75 \\
\hline DCRR & 0 & -6.36 & 0 & -6.35 & -6.42 & -6.44 \\
\hline DEFF & 0 & -6.15 & 0 & -6.10 & -6.18 & -6.18 \\
\hline DEFF_R & 0 & -5.60 & 0 & -5.62 & -5.59 & -5.70 \\
\hline DG10Y & 0 & -6.91 & 0 & -6.98 & -6.77 & -6.84 \\
\hline DGNPA_RA & 0 & -4.97 & 0 & -5.55 & -5.08 & -5.65 \\
\hline$\overline{D L R P}$ & 0 & -5.99 & 0 & -6.64 & -6.40 & -7.08 \\
\hline DLEXCH & 0 & -6.03 & 0 & -6.20 & -5.97 & -6.23 \\
\hline DLVIX & 0 & -8.33 & 0 & -8.26 & -8.52 & -8.54 \\
\hline DSLR & 0 & -5.12 & 0 & -5.42 & -4.98 & -5.17 \\
\hline DLYNAGR & 3 & -3.49 & 3 & -3.50 & -21.06 & -21.08 \\
\hline DUSG1 & 2 & -2.61 & 2 & -2.47 & -4.60 & -4.59 \\
\hline EFF & 0 & -1.89 & 0 & -2.27 & -2.23 & -2.66 \\
\hline EFF_RGAP & 1 & -3.52 & & & & \\
\hline FEDTARGET & 1 & -1.74 & 1 & -2.21 & -1.81 & -1.89 \\
\hline FII_DEBT & 0 & -4.68 & 0 & -4.83 & -4.65 & -4.84 \\
\hline G10Y16Q & 0 & -5.34 & 0 & -4.16 & -3.27 & -2.88 \\
\hline GDPRGAP & 0 & -5.42 & & & & \\
\hline GMB & 0 & -6.19 & 0 & -6.26 & -5.79 & -5.95 \\
\hline INTDIF & 0 & -1.04 & 0 & -3.79 & -1.05 & -3.55 \\
\hline IP & 0 & -3.03 & 0 & -5.54 & -2.78 & -6.08 \\
\hline RMINOILGAP & 0 & -2.53 & & & & \\
\hline RNFCGAP & 2 & -2.58 & & & & \\
\hline RAIN & 0 & -8.28 & 0 & -8.23 & -8.39 & -8.40 \\
\hline PRD & 0 & -5.39 & 0 & -5.35 & -5.48 & -5.48 \\
\hline REERGAP & 2 & -4.81 & & & & \\
\hline LIAB & 0 & -0.15 & 0 & -2.82 & -0.42 & -2.78 \\
\hline WEXPGAP & 1 & -5.48 & & & & \\
\hline YAGRIGAP & 2 & -5.86 & & & & \\
\hline
\end{tabular}




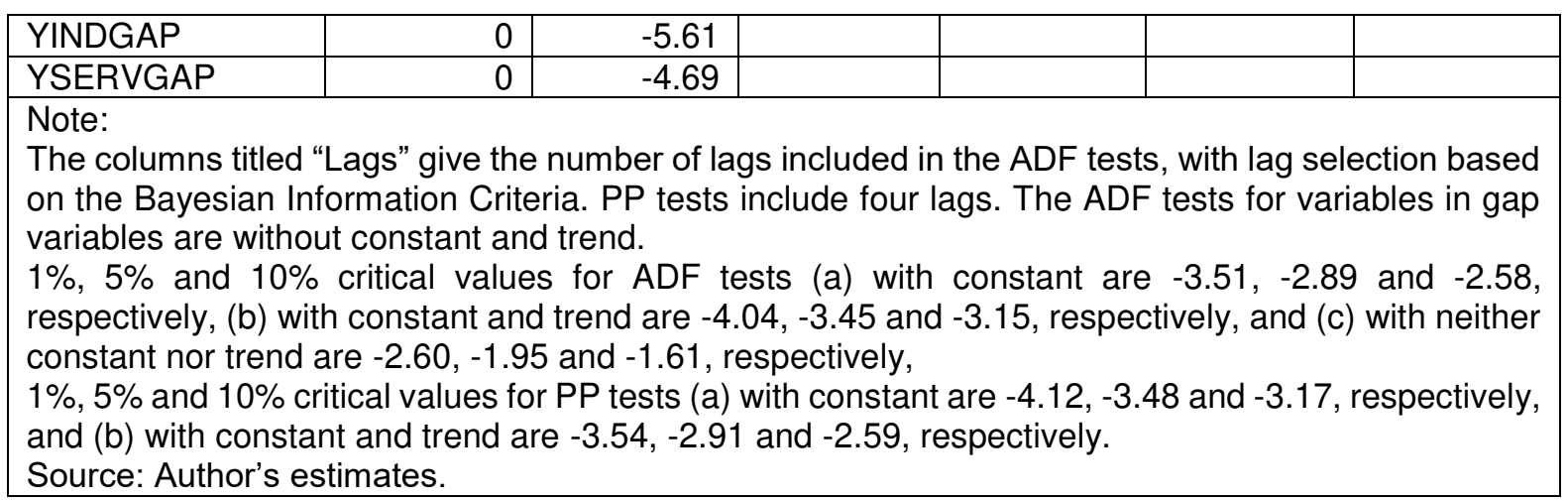




\begin{tabular}{|l|r|r|r|}
\hline \multicolumn{5}{|c|}{ Table 3: Model's Forecasting Performance: Theil's U } \\
\hline Variable & $\begin{array}{r}\text { One-quarter ahead } \\
\text { forecast }\end{array}$ & $\begin{array}{r}\text { Four-quarter ahead } \\
\text { forecast }\end{array}$ & $\begin{array}{r}\text { Eight-quarter } \\
\text { ahead forecast }\end{array}$ \\
\hline YAGRIGAP & 0.71 & 0.52 & 0.41 \\
\hline YINDGAP & 0.62 & 0.58 & 0.39 \\
\hline YSERV_XGAP & 0.75 & 0.71 & 0.56 \\
\hline GDPRGAP & 0.69 & 0.73 & 0.50 \\
\hline DALGDPR & 0.58 & 0.61 & 0.55 \\
\hline D4LCPIEXFF & 0.65 & 0.54 & 0.45 \\
\hline D4LCPIFOOD & 0.44 & 0.49 & 0.55 \\
\hline DALCPIEXFF & 0.49 & 0.52 & 0.33 \\
\hline DALCPIFOOD & 0.45 & 0.76 & 0.76 \\
\hline DALCPI & 0.45 & 0.68 & 0.61 \\
\hline DLEXCH & 0.65 & 0.65 & 0.53 \\
\hline DALNFC & 0.66 & 0.64 & 0.44 \\
\hline GNPA_RA & 0.58 & 0.49 & 0.45 \\
\hline CAP & 0.79 & 0.63 & 0.75 \\
\hline CAB & 0.72 & 0.70 & 0.68 \\
\hline PRD & 0.71 & 0.89 & 0.60 \\
\hline IP & 0.69 & 0.34 & 0.33 \\
\hline GFD & 0.60 & 0.77 & 0.54 \\
\hline G10Y & 0.68 & 0.74 & 1.16 \\
\hline Source: Author's estimates. & & & \\
\hline
\end{tabular}




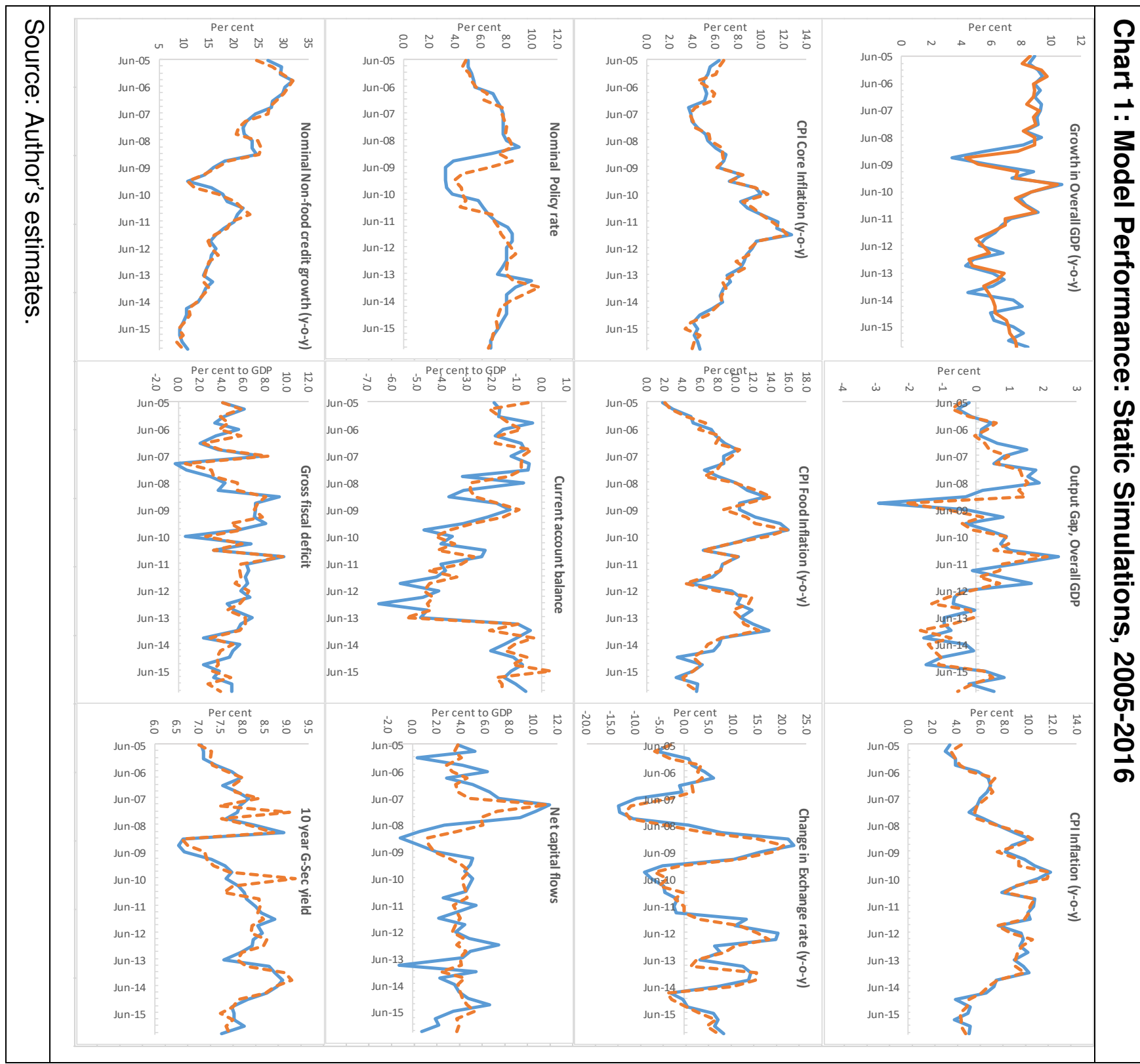




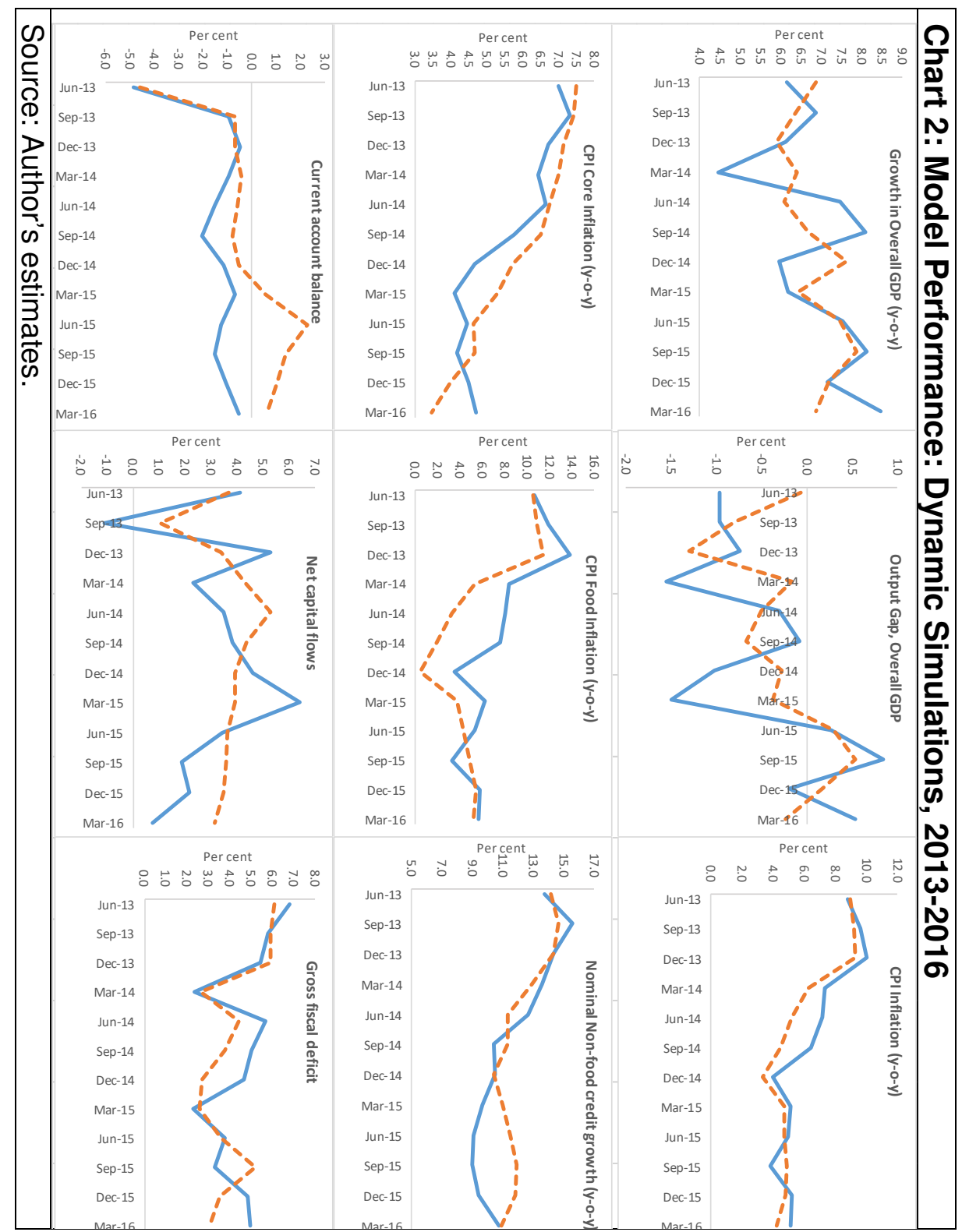




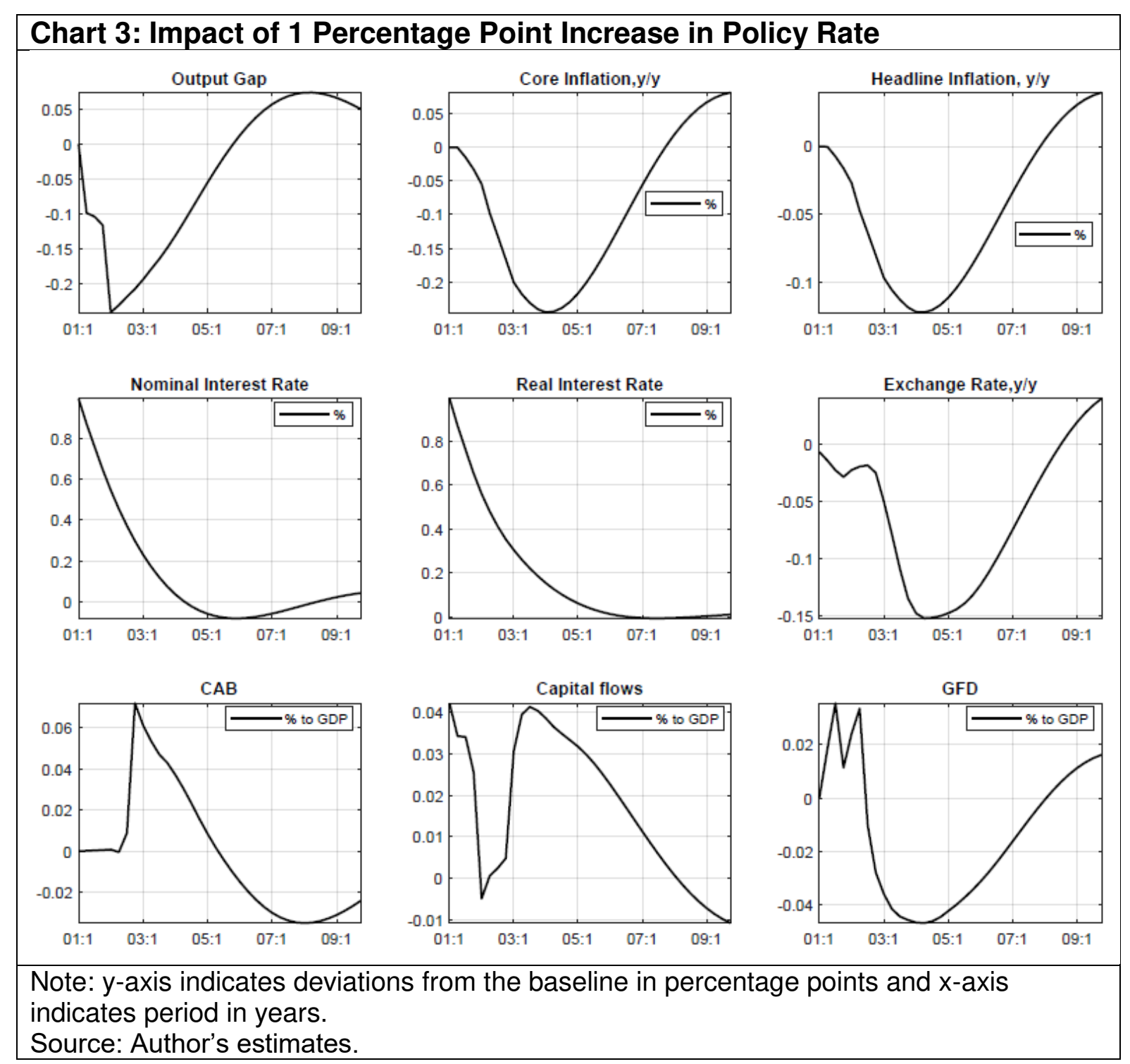




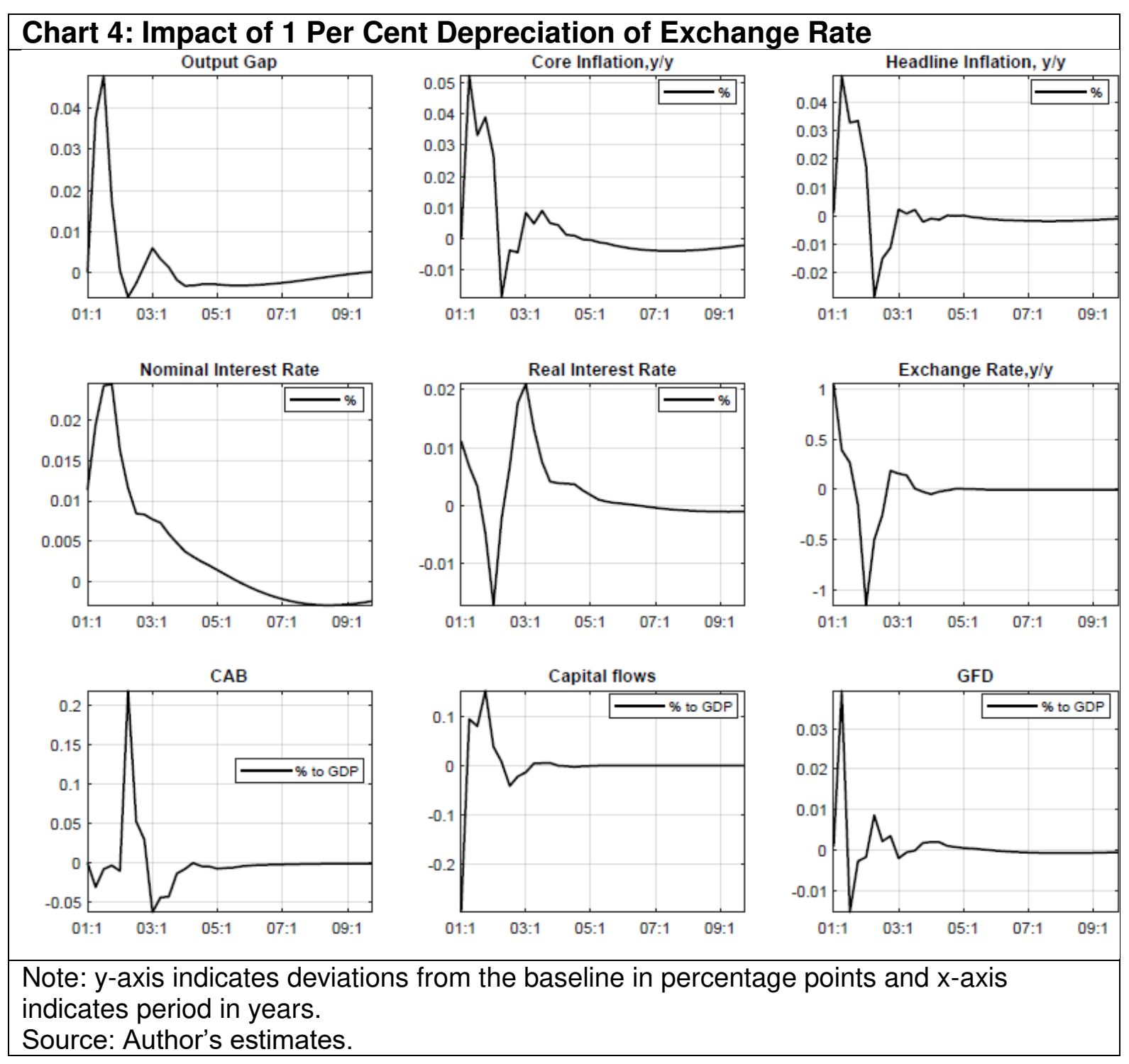




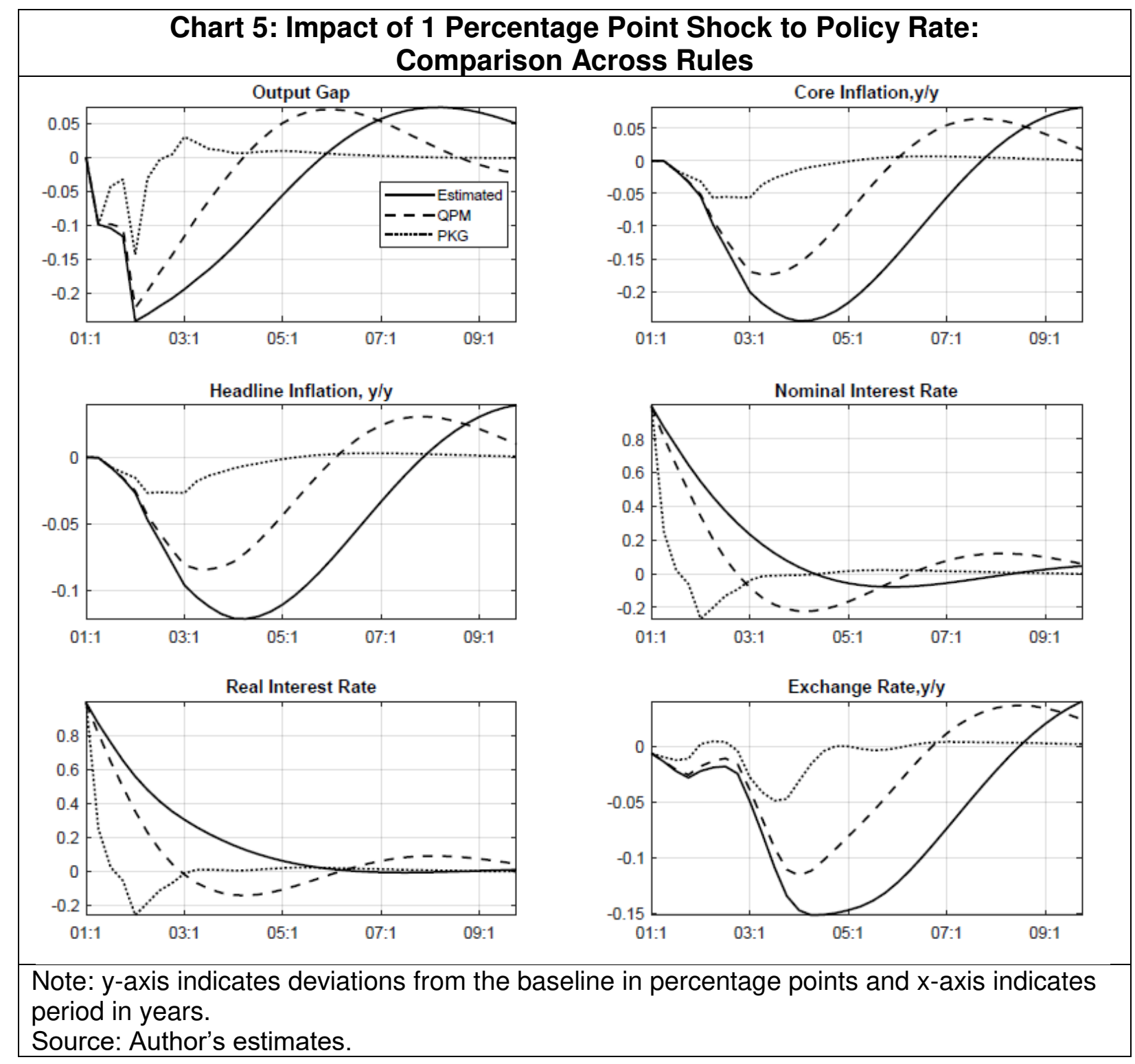




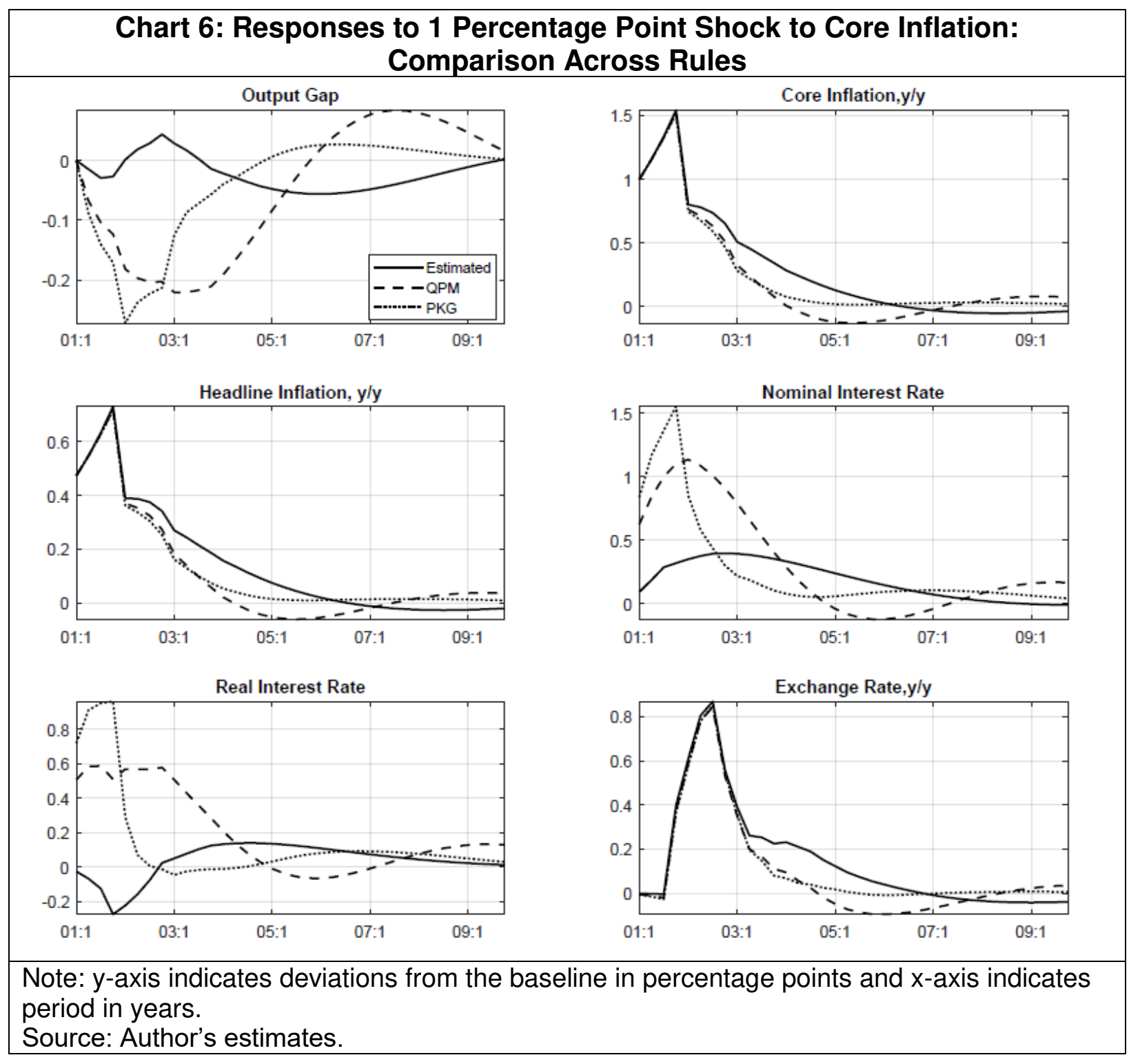




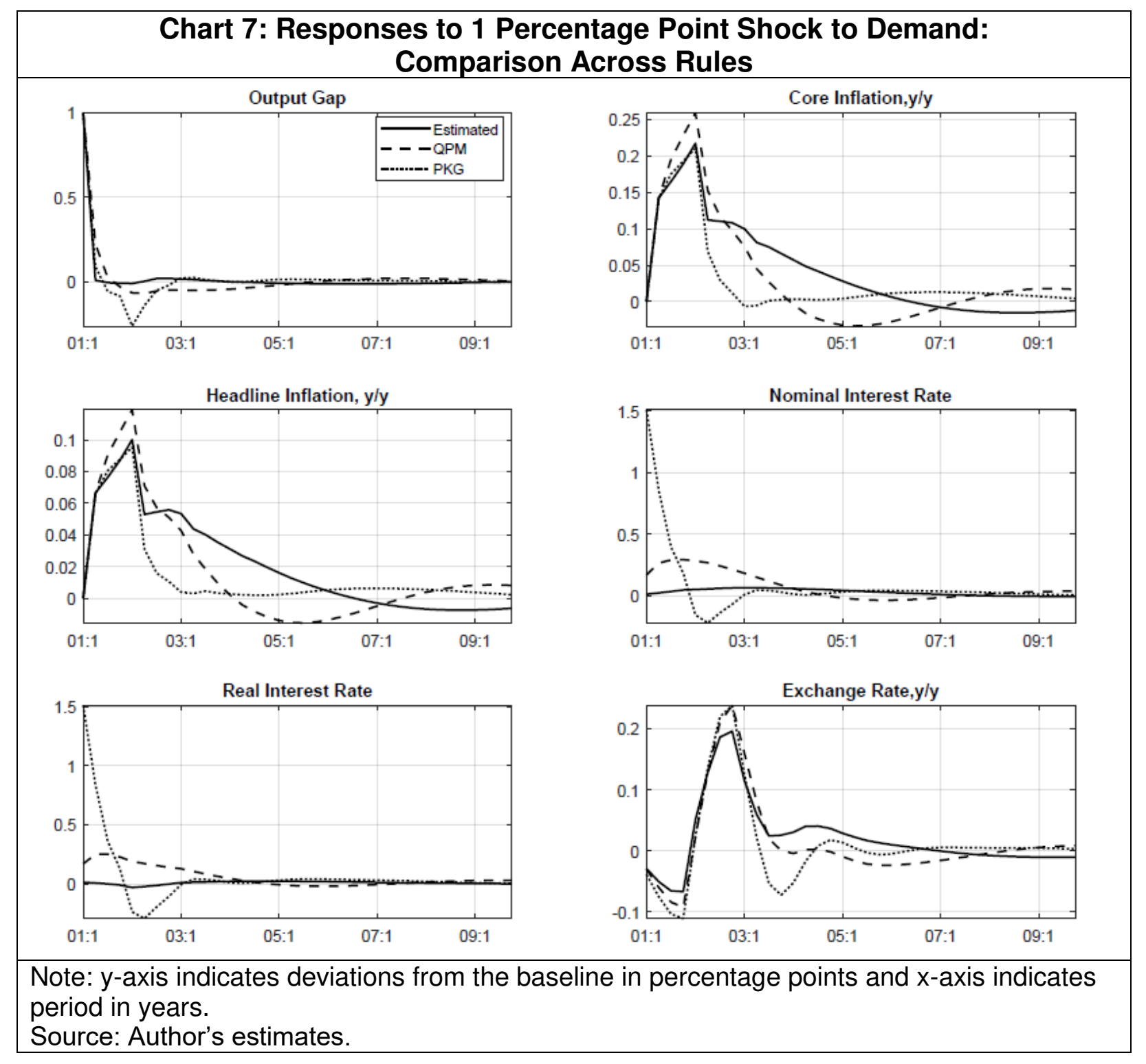




\section{Annex l:}

\section{Overall Monetary Transmission: Cross-Country Empirical Evidence}

Cross-country empirical evidence indicates that monetary policy impacts growth and inflation with long and variable lags (Annex Table 1). Illustratively, according to Christiano et al. (1999) - a benchmark study in the area and using the VAR methodology - an increase of 100 bps in the federal funds rate leads to a peak reduction of around 50 bps in output (GDP) after 6 quarters and a reduction of around 40 bps in inflation after 12 quarters $^{23}$. The selective survey in Annex Table 1 suggests a wide variation in lags as well as the quantum of the impact: ignoring the out-sized effects of the Romer and Romer (2004) study ${ }^{24}$, a 100 basis points (bps) tightening of interest rate shows a peak decline in output of 12-70 bps, with a lag of 1-10 quarters; the corresponding peak effect on inflation is 4-88 bps with a lag of 3-12 quarters.

There is some evidence that monetary policy may have become less effective since the 1990s: the peak impact of a 100 bps fed funds rate tightening on industrial production using the VAR framework of Christiano et al. (1999) was 48 bps for the period 1965-1996, but only 20 bps for the period 1959-2007 (Ramey, 2016). Similarly, using the Romer and Romer (2004) narrative framework, the estimated impact on industrial output declines from 1.4 per cent during 1969-1996 to 0.8 per cent during 1969-2007 (Annex Table 2). The changes in the monetary policy impact can be quite striking across different approaches, different assumptions and different sample periods (Barakchian and Crowe, 2013; Coibion, 2012).

Estimates of peak impact and lags are averages over the study periods and the actual impact of each monetary tightening/easing cycle on output and inflation could differ, depending upon the surrounding macroeconomic and financial environment as well as the evolving structure of the economy, the pace of the financial innovations and across models (Olsen, 2011). For example, the analysis for the US in Willis and Cao (2015) suggests a decline in the interest sensitivity of employment for nearly all industries and for the overall economy. They attribute the declining sensitivity, inter alia, to a weaker impact of short-term policy rate on long-rates.

The relatively smaller impact of monetary policy on output and prices in Japan could perhaps be a reflection of the reduced efficacy of monetary policy in view of near zero policy interest rates since the mid-1990s (Fukunaga et al., 2011). More broadly, with policy rates in the vicinity of the zero lower bound in a number of advanced economies since 2009 , the efficacy of monetary transmission through the conventional interest rate channel as well as through the unconventional channel (quantitative easing/large scale asset purchases) appears to be increasingly diminishing (BIS, 2016).

23 These numbers are from their Figure 2 (column 1).

${ }^{24}$ The large effects in the Romer-Romer paper are driven by: (a) a stronger contractionary shock, (b) disproportionate effect during the reserves averaging period (1979-82), and (c) the use of longer lags in their specifications (Coibion, 2012). 
Monetary policy impact may also depend upon financial conditions and be nonlinear: monetary policy has stronger and more persistent effects on macroeconomic variables such as output, consumption and investment during periods of high financial stress than during 'normal' times (Dahlhaus, 2017). Stronger effect during stress times suggests that balance sheet channel and bank-lending channel are at play.

Acharya et al. (2015), Dell'Ariccia et al. (2016) and Karapetyan (2016) find evidence in support of the risk-taking channel in euro area, the US and Norway. The quality of lending - measured by the risk rating of new loans - goes down when monetary policy turns accommodative. Although the impact is statistically significant and robust, Dell'Ariccia et al. (2016) note that the economic magnitude is relatively small. On the role of the bank's balance sheet strength and composition in inducing the risk-taking, Acharya et al. (2015) and Karapetyan (2016) find that less capitalized banks are more likely to increase loan volumes to ex-ante risky firms and indulge in ever-greening of bad loans and zombie lending, compared to more capitalized banks, consistent with the search for yield hypothesis. On the other hand, according to Dell'Ariccia et al. (2016), risk taking is more pronounced for more capitalized banks, as equity owners of such banks might have a greater incentive to transfer risk onto its debt holders.

As regards emerging economies, Mallick and Sousa (2012) find that contractionary monetary policy has a strong and negative effect on output in the BRICS (Brazil, Russia, India, China, and South Africa); tight monetary policy has the expected stabilising impact on inflation, albeit relatively moderate compared to the output effect and there is also some heterogeneity across the sample countries. Transmission lags may be relatively shorter in some EMEs, attributable to shorter maturity of domestic credit, and the considerable weight of the exchange rate in domestic currency pricing (Catão et al., 2008). Monetary transmission may be effective in low income countries, although the VAR based studies may not be able to capture the dynamics, given the limited time-series data available, measurement errors and large structural breaks (Li et al., 2016).

A comprehensive meta-analysis of monetary transmission to prices (focusing only on studies using the VAR framework) is attempted by Havranek and Rusnak (2013) and Rusnak, Havranek and Horvath (2013). Havranek and Rusnak's (2013) meta-analysis of 67 studies covering 30 countries finds: (a) the peak effect of a monetary policy shock on inflation occurs 29 months after the shock ${ }^{25}$, (b) the peak lag differs substantially across studies and countries, ranging from 11 months (Slovakia) to 51 months (Japan and France), (c) the peak effect lags are relatively longer in advanced economies (vis-à-vis transition countries), which suggests more financial development increases transmission lags, and, (d) the lags are typically longer is studies using quarterly data vis-à-vis studies using monthly data. The related meta-analysis by these authors (Rusnak, Havranek and Horvath, 2013) of 70 studies ${ }^{25}$ The peak lag is substantially shorter ( 16 months) in hump-shaped impulses responses than
that of around 50 months in strictly decreasing impulse responses. 
covering 31 countries suggests a relatively faster pace of transmission: an increase of $100 \mathrm{bps}$ in interest rates leads to a peak decline of $33 \mathrm{bps}$ in prices after 6 months, with the impact moderating to 22 bps after 12 months from the initial shock. The impact turns statistically insignificant after 13-14 months and reduces to 12 bps after 36 months. The impact is stronger in more open economies, in countries with more independent central banks, and in economic downturns. The empirical findings of these two meta studies are somewhat puzzling and are not reconciled by the authors: the peak effect occurs after 29 months in Havranek and Rusnak (2013) and after just 6 months in Rusnak, Havranek and Horvath (2013). One possible explanation for this might be different yardsticks in the two studies. The analysis in Rusnak, Havranek and Horvath (2013) is based on "best practice" studies, and the peak lag in Havranek and Rusnak (2013) reduces from 29 months for all the included studies to 16 months for the studies with hump-shaped impulse responses. This narrows the gap between the peak lags in the two studies, but still remains substantial. 


\section{Annex II: \\ Empirical Evidence on Overall Monetary Transmission for India: \\ VAR and Related Studies}

According to the structural VAR (SVAR) model in Mohanty (2012), the peak effect on output takes with a lag of two quarters and that on inflation with a lag of three quarters. An assessment of the expenditure side GDP components in a VAR framework indicates that monetary policy has a strong impact on investment demand, while the impact on private consumption is subdued (Khundrakpam, 2012). Dhal (2012) studies the impact of interest rate across industry groups in a VAR framework and finds a relatively stronger effect of interest rates on capital goods and consumer durables relative to basic, intermediate and consumer non-durable goods, although definitive conclusions are hindered by wide asymptotic standard error bands. The effect of the stock market wealth shock on consumption demand in India is relatively small, given the low share of stock wealth in the household asset portfolio and its asymmetric distribution (Singh, 2012). Bhoi et al. (2016) employ 'shutdown' methodology in a VAR framework to study the relative importance of alternative channels of monetary policy transmission and find the interest rate channel to be the most dominant channel. In response to a shock to the operating target, the maximum decline in output growth occurs with a lag of 2-3 quarters, and that on inflation (both $\mathrm{CPI}$ and $\mathrm{WPI}$ ) with a lag of 3-4 quarters.

In emerging economies such as India, unique institutional details as well as the thinness of financial markets in the backdrop of increasing global integration can result in unstable and perverse monetary transmission. Frictions such as statutory liquidity ratio (SLR) and chronic fiscal deficits can, under some conditions, completely invert the monetary transmission mechanism: (a) when the SLR constraint binds, a reduction in the policy rate can end up raising lending spreads and a contraction, instead of an expansion, in the economy, and (b) an exogenous fiscal constraint and a binding SLR may result in inflation rising in response to a tight monetary policy (Lahiri and Patel, 2016). Mishra et al. (2016) using a monthly VAR for the period 2001-2014 find some impact of monetary policy impulses on exchange rate and commercial banks' lending rate but no impact on either output or inflation - the authors attribute the latter finding to either instability in monetary transmission or the limitations of the empirical methodology.

Banerjee et al. (2018) focus on the role of financial frictions and structural rigidities in monetary transmission in a DSGE model with an imperfectly competitive banking sector at the core. Their results suggest that easing of the collateral constraint and greater financial inclusion can enhance the degree of transmission more than proportionately, and interest rate rigidity on the lending side is more critical than the rigidity on the deposit side. Targeting financial stability through monetary policy rule may not be appropriate for the purpose of economic stabilisation.

The constant natural interest rate assumption implicit in Taylor type feedback rules could be misleading at times, in view of possible time-varying nature of the 
natural interest rate (Behera, Pattanaik and Kavediya, 2015). Time-varying natural rate estimates suggest that the real interest rate gap (actual rate less the natural rate) was negative in India for a major part of 2005-15, implying that monetary policy stance was largely accommodative rather than anti-inflationary. 


\begin{tabular}{|c|c|c|c|c|c|c|}
\hline \multicolumn{7}{|c|}{$\begin{array}{c}\text { Annex Table 1: Monetary Policy Impact on Output and Inflation: } \\
\text { Cross-country Survey } \\
\text { (Impact of } 100 \text { basis points (bps) Increase in Interest Rate) }\end{array}$} \\
\hline No. & Country & $\begin{array}{l}\text { Study and } \\
\text { Modelling Approach }\end{array}$ & $\begin{array}{r}\text { Peak } \\
\text { reduction } \\
\text { in GDP } \\
\text { (bps) } \\
\end{array}$ & $\begin{array}{r}\text { Lag } \\
\text { (quarters) }\end{array}$ & $\begin{array}{r}\text { Peak } \\
\text { reduction } \\
\text { in inflation } \\
\text { (bps) } \\
\end{array}$ & $\begin{array}{r}\mathrm{Lag} \\
\text { (quarters) }\end{array}$ \\
\hline 1 & USA & $\begin{array}{l}\text { Christiano et al. } \\
\text { (1999) ; VAR (a) }\end{array}$ & 50 & 6 & 40 & 12 \\
\hline \multirow[t]{3}{*}{2} & \multirow[t]{3}{*}{ USA } & $\begin{array}{l}\text { Romer and Romer } \\
(2004)\end{array}$ & & & & \\
\hline & & $\begin{array}{l}\text { Narrative plus } \\
\text { regression }\end{array}$ & 430 (IP) & 8 & $\begin{array}{l}590(\mathrm{PPI}) \\
360(\mathrm{CPI})\end{array}$ & 16 \\
\hline & & Narrative plus VAR & $290(\mathrm{IP})$ & 8 & 500 (PPI) & 16 \\
\hline 3 & USA & $\begin{array}{l}\text { Boivin et al. (2011); } \\
\text { DSGE (b) }\end{array}$ & 40 & 2 & 30 & 3 \\
\hline 4 & $\begin{array}{l}\text { Euro } \\
\text { area }\end{array}$ & $\begin{array}{l}\text { Els et al. (2003); } \\
\text { VAR and macro } \\
\text { models }\end{array}$ & $30-70$ & 8 & $20-40$ & 3 \\
\hline 5 & UK & $\begin{array}{l}\text { BoE (2000); macro } \\
\text { model }\end{array}$ & 30 & 4 & 30 & 9 \\
\hline 6 & UK & $\begin{array}{l}\text { Cloyne and } \\
\text { Hürtgen (2015); } \\
\text { Romer-Romer } \\
\text { approach in VAR }\end{array}$ & 50 & 10 & 88 & 12 \\
\hline 7 & Sweden & $\begin{array}{l}\text { Bardsen et al. } \\
\text { (2011); DSGE }\end{array}$ & 50 & 6 & 20 & 6 \\
\hline \multirow[t]{2}{*}{8} & \multirow[t]{2}{*}{ Norway } & Olsen, 2011; VAR & $40-70$ & $5-6$ & $20-30$ & $9-11$ \\
\hline & & Olsen, 2011; DSGE & 40 & 5 & 25 & 8 \\
\hline 9 & Japan & $\begin{array}{l}\text { Fukunaga et al. } \\
\text { (2011); macro } \\
\text { model }\end{array}$ & 14 & 7 & 4 & 10 \\
\hline 10 & Poland & $\begin{array}{l}\text { Pruski and Szpunar } \\
(2008)\end{array}$ & 30 & 4 & 20 & 8 \\
\hline 11 & Brazil & Catao et al. (2008) & 12 & 2 & 40 & 3 \\
\hline 12 & Chile & $\begin{array}{l}\text { Garcia et al. (2005); } \\
\text { macro model }\end{array}$ & 60 & 1 & 25 & 7 \\
\hline 13 & $\begin{array}{l}\text { Czech } \\
\text { Republic }\end{array}$ & \multirow[t]{3}{*}{$\begin{array}{l}\text { Anzuini and Levy } \\
\text { (2007); VAR }\end{array}$} & $16(\mathrm{IP})$ & 3 & 34 & 8 \\
\hline 14 & Hungary & & 200 (IP) & 1 & 80 & 11 \\
\hline 15 & Poland & & $40(\mathrm{IP})$ & 3 & 30 & 5 \\
\hline 16 & Thailand & $\begin{array}{l}\text { Disyatat and } \\
\text { Vongsinsirikul } \\
\text { (2003) }\end{array}$ & 41 & 4 & 12 & 12 \\
\hline
\end{tabular}




\begin{tabular}{|c|r|r|}
\hline \multicolumn{2}{|c|}{ Annex Table 2: Monetary Policy Effect on Output: Sensitivity Analysis } \\
\hline Paper and Method & Sample Period & $\begin{array}{r}\text { Trough Impact on } \\
\text { Industrial Production of } \\
\text { an Increase of 100 bps in } \\
\text { the Federal Funds Rate } \\
\text { (Per cent) }\end{array}$ \\
\hline (a) Christianio et al. (1999), VAR & & -0.48 \\
\hline & $1965 \mathrm{~m} 1-1996 \mathrm{~m} 6$ & -0.20 \\
\hline & $1959 \mathrm{~m} 1-$ & -1.38 \\
\hline (b) Romer and Romer (2004) & $2007 \mathrm{~m} 12$ & -0.83 \\
\hline (i) VAR & & -0.83 \\
\hline (ii) VAR & $1969 \mathrm{~m} 3-$ & -0.90 \\
\hline (iii) Jorda approach & $1996 \mathrm{~m} 12$ & \\
\hline (iv) Jorda approach, no & $1969 \mathrm{~m} 3-$ & $-2007 \mathrm{~m} 12$ \\
\hline recursiveness & $1969 \mathrm{~m} 3-$ & -2.2 \\
\hline (c) Gertler and Karadi (2015) & $1996 \mathrm{~m} 12$ & \\
\hline (i) Proxy SVAR & $1969 \mathrm{~m} 3-$ & \\
\hline (i) Jorda approach & $1996 \mathrm{~m} 12$ & \\
\hline Source: Ramey (2016, Table 3.2) & & \\
\hline
\end{tabular}

